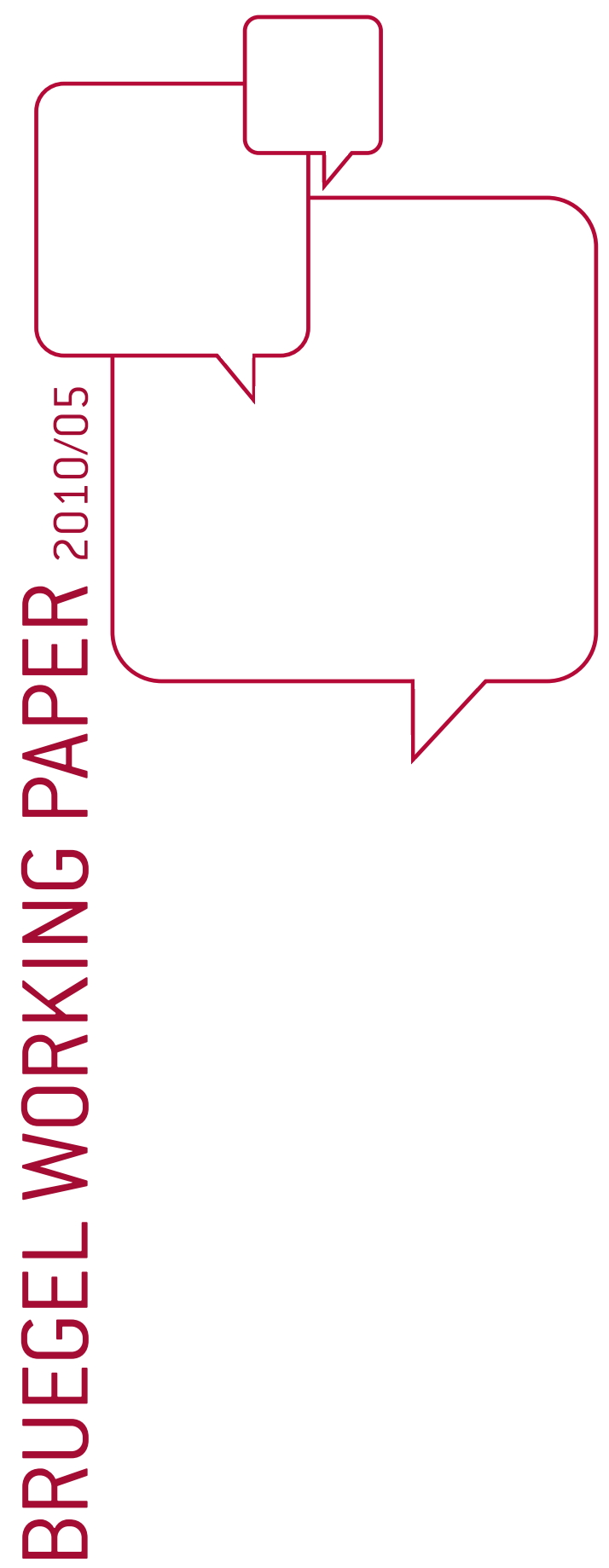

\title{
REFORM OF THE GLOBAL FINANCIAL ARCHITECTURE
}

GARRY J. SCHINASI AND EDWIN M. TRUMAN

Highlights

- This paper examines the implications of the global financial crisis of 2007-10 for reform of the global financial architecture, in particular the International Monetary Fund and the Financial Stability Board and their interaction. These two institutions are not fully comparable, but they must work more closely in the future to help prevent global financial crises. To this end, the paper identifies institutional and substantive reforms separately and in their joint work that would be desirable and appropriate.

JEL codes: F30, F33, F36, F53, G28

Keywords: International Monetary Fund, Financial Stability Board, Bank for International Settlements. Group of Twenty, banking supervision and regulation, financial crises, financial stability, financial reform

Garry J Schinasi is an independent advisor on financial stability issues and a visiting fellow at Bruegel (www.bruegel.org).

Edwin M Truman is a senior fellow at the Peterson Institute for International Economics (www.piie.com).

Note: This paper was prepared for a conference sponsored by Bruegel and the Peterson Institute for International Economics held on October 8, 2010, as part of a project, sponsored by the European Commission, on transatlantic relationships in an era of growing economic multi-polarity. The authors thank Morris Goldstein and Larry Promisel for their comments on an earlier draft. The views expressed in this paper are the authors' own. 


\section{INTRODUCTION}

It is now more than three years since the onset of the global financial and economic crisis and two years since the global market dysfunctioning that occurred in the aftermath of the public bankruptcy of Lehman Brothers and the US government takeover of AIG. Although some progress has been made in reforming financial-sector policies and the International Monetary Fund (IMF) and Financial Stability Board (FSB), the bulk of reforms required to improve the ability to safeguard global financial stability and resolve global crises have yet to be agreed much less fully legislated and implemented. ${ }^{1}$

Against this background, this paper examines the implications of the global crisis for reform of the global financial architecture (GFA), focusing in particular on areas where further reforms of the IMF and FSB could help to improve the functioning and governance of the global financial system. The paper is organised as follows: The next section examines the precrisis framework for safeguarding global financial stability and identifies six key areas where financial-system reforms are necessary. The following section focuses on the IMF and the FSB (the successor to the Financial Stability Forum [FSF]) and their recent and prospective reforms. The penultimate section discusses the interaction of the issues identified in the second section with the institutions discussed in the second-to-last section. The last section provides our key conclusions and recommendations.

In summary, we conclude that the IMF and FSB are distinct and not fully comparable institutions, but they must cooperate more closely than in the past on the reform and performance of the global financial system. No other global financial architecture is up to the task and is politically feasible at this time. To that end, we outline the key tasks that the IMF and FSB should address.

We make recommendations for substantive and institutional governance reforms of both the IMF and FSB; reorientation of central banks vis-à-vis the IMF and vice versa and vis-à-vis macroprudential policies; and using the FSB-IMF collaborative structure to help address the troubling issue of global capital flows.

We also recommend a number of institutional reforms: adding expert staff resources to both the IMF and FSB, formalising the reporting by the FSB to the International Monetary and Financial Committee (IMFC), adopting an inclusive policy agenda, and more direct engagement by the IMF in the work of the FSB.

Before proceeding to our analysis, the remainder of this introduction provides some definitions and sets the stage.

The main focus of our analysis is the global financial system (GFS) and its supporting GFA. The GFS consists of the global (international) monetary system with its official understandings, agreements, conventions, and institutions as well as the private and official processes, institutions, and conventions associated with private financial activities. ${ }^{2}$ For completeness, we refer to Gold's definition of the international (global) monetary system, which consists of the rules governing the relations of countries through their balance of payments and the monetary authorities that manage them (treasuries, central banks, stabilisation funds, and other country-specific institutions (Gold 1981).

\footnotetext{
${ }^{1}$ For some of the many reform recommendations see: UK Treasury (2009); US Treasury (2009); European Commission (2009); de Larosière (2009); G-30 (2009); UK Financial Services Authority (2009); Committee on Capital Markets Regulation (2009); FSB (2008); G-20 (2009); Issing Committee (2009); and IMF (2009).

2 This definition is a slight modification of the definition in Truman (2003).
} 
The global financial system has three components: private sector institutions, the nations that have supervisory jurisdiction over the private institutions, and the international institutions through which the national authorities coordinate and cooperate. The GFA is the collective governance arrangements at the global level for safeguarding the effective functioning (or the stability) of the global financial system. ${ }^{3}$ The GFA is governed first and foremost by the countries that have agreed to be part of it, for example, through their IMF membership, their participation in other institutions and agreements, and their adherence to various codes, standards, and understandings. Accordingly, accountability for the successes and failures of the GFA rests squarely with its member countries, in particular those that strongly influence it. These same countries are accountable to their own constituencies for the performance of the GFA and any implications its performance may have on national, regional, continental, and global economic and financial outcomes.

The global financial and economic crisis of 2007-10 revealed that the precrisis GFA was flawed both in its implementation and in its structure. With the benefit of hindsight, there were warning signs and policy mistakes and misjudgments. But as structured and implemented, the GFA was not effective in encouraging or persuading remedial actions at the national, regional, continental, or global level until a full-scale global systemic crisis was a reality to be dealt with. As Stanley Fischer (2009) wisely observes, warnings are one thing, but they are worth little unless they lead to meaningful actions.

The GFA was revealed to be structurally flawed. Its coordination mechanisms failed to resolve cross-border problems without the resort to national ring-fencing, unprecedented volumes of liquidity provided by central banks to markets, and volumes of credit guarantees and recapitalisations provided by national treasuries to individual financial institutions not previously witnessed on a global scale. In light of the need for unprecedented massive interventions, one important and perhaps overriding lesson for global governance emerging from the crisis is that the international community lacks a body of international law, or at least official agreements and conventions, and importantly ex ante, burden-sharing mechanisms (or balance sheets) for resolving the weaknesses or insolvencies of large, complex, interconnected financial conglomerates.

Table 1 summarises the IMF's and FSB's policy mandates, tools, and governance structures. As discussed in more detail in the body of this paper, the FSB is the successor body to the FSF. It has a broader membership and remit, but its basic structure remains the same as that of the FSF.

As the table demonstrates, the IMF has concrete policy instruments and substantial resources: It lends, engages in bilateral and multilateral surveillance (evaluations), and it provides technical assistance for improving macroeconomic and financial-sector policymaking in member countries. By contrast, the FSF was, and the FSB is, primarily a coordinating body. The FSF's advanced-country membership, before the crisis, used the FSF to try to form consensus about best practices in microprudential regulation and supervision for all countries as well as to identify vulnerabilities in the GFS and supervisory gaps. Neither the IMF nor the FSF had the policy instruments to prevent or resolve financial crises involving private financial institutions and markets. They can hardly be held fully accountable for not preventing or resolving the global crisis of 2007-10. But, as institutions, the IMF and FSF (including their managements and staffs) can and should be held accountable for failing to deliver what was expected—such as candid

\footnotetext{
${ }^{3}$ Here we have adapted Elson's (2010) definition to suit our purposes.
} 
assessments of the impending financial system imbalances and more effectively pressuring their membership and constituencies to adopt remedial measures to safeguard stability.

Although the IMF and the FSB, and the FSF before it, have been tasked to cooperate on assessing systemic risks and vulnerabilities and share a common purpose in providing financial stability-enhancing global public goods, they are very different types of organisations.

As is clear from its Articles of Agreement, the IMF was established by a formal international agreement that was ratified by governments. It was organised to promote international monetary cooperation and stability as well as to provide other public goods. As such, it should be viewed as an organisation that has an identity separate from and in some respects transcending its country membership. In addition, the IMF is constituted with a management and staff structure separate from its governing or executive boards but with the mandate to pursue the objectives of the IMF. In addition to speaking on behalf of the organisation, staff are also free, subject to quality controls, to publicise their professional research, analyses, and policy judgments on matters of concern to the Fund and its membership, of course with the appropriate disclaimers. Both management and staff do so frequently and at times forcefully. For example, the two leading publications of the IMF-the World Economic Outlook and the Global Financial Stability Report-express the views of the IMF staff and not those of the IMF as an organisation.

Like the IMF, the FSF and FSB charters also make clear that their respective mandates entail the provision of global public goods that transcend its membership: the development and promotion of effective global regulatory, supervisory, and financial sector policies and assessing financial system vulnerabilities that threaten the global financial system. However, the roles of the FSB chair and secretariat are to represent the FSB and its views, not to express views independent of its members.

\section{Global Financial Systemic Issues Revealed by the Crisis}

The global crisis revealed fundamental weaknesses in the precrisis global financial architecture for preventing, managing, and resolving crises in the GFS. This section concludes, not surprisingly, that all lines of defense against a systemic crisis were breached during the crisis. This section highlights the principal areas where reforms are necessary.

\section{Precrisis Framework for Safeguarding Global Financial Stability}

The precrisis framework for safeguarding financial stability and encouraging economic and financial efficiency can be seen as lines of defense against systemic problems that could threaten stability. It was put in place over time by both private and public stakeholders in the major financial centres. ${ }^{4}$ This architecture evolved over time as events occurred. It is the result of neither a grand design nor an underlying "genetic" code that predisposed the evolution of the system to emerge in the way it has. It is more akin to an evolving patchwork quilt of consensus decisions by stakeholders in the major financial centres to deal with problems as they emerged and as an organic collection of private and public international agreements and conventions.

A simplified framework of potential threats to stability and of the lines of defense against them is summarised in table 2. The columns of the table represent four important sources of global systemic financial risk: (1) global financial institutions-primarily large, international

\footnotetext{
${ }^{4}$ This subsection is adapted from the framework in Schinasi (2009a).
} 
banks/groups but also including global investment banks and insurance/reinsurance companies;

(2) global financial markets-foreign exchange, bond, and over-the-counter derivatives markets;

(3) unregulated financial-market activities of institutional investors such as the capital markets activities of insurance and reinsurance companies and of mutual, pension, and hedge funds; and (4) economic and financial-stability policy mistakes.

Financial infrastructures could be added as another source of systemic risk but they are excluded for simplicity. By and large, clearance, settlement, and payments systems performed reasonably and comparatively well during the crisis. There are some notable exceptions, such as the repo market, but problems there were related to the weaknesses that surfaced in the financial institutions that are the major counterparties in the repo markets. More generally, the large global banks typically are the major participants in national and international clearance, settlement, and payments infrastructures_-both public and private-as well as the major trading exchanges. Many of these financial institutions co-own parts of the national and international infrastructures and have a natural interest in their performance, stability, and viability. Incentives are to some extent aligned to achieve both private and collective net benefits.

Increasingly, however, internationally active banks have been more heavily involved in over-the-counter (OTC) transactions, which do not pass through these infrastructures. This poses systemic risk challenges, many of which surfaced dramatically during the global financial crisis and earlier during the Long-Term Capital Management (LTCM) crisis. In addition, broader aspects of finance can also be considered as part of the infrastructure and pose systemic riskssuch as the frameworks for risk management (grounded heavily in value-at-risk or VAR models), the very notion and practical meaning of risk diversification, important market segments that provide essential "utility" and "liquidity" services to the broader market place, such as the repo market and swaps markets, accounting rules and practices, corporate governance and compensation practices, and supervisory and regulatory standards and practices (Garber 2009).

The rows of table 2 represent what can be characterised as lines of defense against systemic problems: (1) market discipline-including private risk management and governance, along with adequate disclosure via financial reporting and market transparency; (2) financial regulations - which define the rules of the game for transactions and relationships; (3) microprudential supervision of financial institutions and products; (4) macroprudential supervision of markets and the financial system as a whole; and (5) crisis management and resolution.

As indicated in the first column of table 2 labelled "Global Financial Institutions," large cross-border banking groups are within the perimeter of all five lines of defense. As such, these financial institutions are the most closely regulated and supervised commercial organisations on the planet, and for good reasons. These institutions pose financial risks for depositors, investors, markets, and even unrelated financial stakeholders because of their size, scope, complexity, and of course their risk management systems, which may permit excessive, often highly leveraged, risk taking. Some of them are intermediaries, investors, brokers, dealers, insurers, reinsurers, infrastructure owners and participants, and in some cases many of these roles exist within a single complex institution. They are systemically important: all of them nationally, many of them regionally, and about 20 or so of them globally. Protection, safety net, and systemic risks issues are key public policy challenges. Oversight of these institutions occurred at the national level, through both market discipline and official involvement, with a degree of indirect surveillance carried out at the international level through the IMF, the Organisation for Economic Cooperation and Development (OECD), and the Bank for International Settlements (BIS), and 
committees and groups, including the Basel Committee and Financial Stability Forum prior to the crisis.

At the other extreme of regulation and supervision are unregulated financial activities (and entities), as can be seen in the third column of table 2. These financial activities and entities are neither regulated nor supervised. Many of the financial instruments-OTC derivatives for example, used strategically and tactically by these unregulated entities-are not subject to formal securities regulation. ${ }^{5}$ Moreover, the markets in which they transact are by and large the least regulated and supervised. This lack of regulation, supervision, and surveillance is often the basis for their investment strategies and it defines the scope of their profit making. Unregulated entities (such as hedge funds and certain kinds of special investment vehicles [SIVs]) are forbidden in some national jurisdictions. In jurisdictions where they are partially regulated, this is tantamount to being forbidden - given the global nature and fungibility of their business models. Some market activities of unregulated entities are subject to market surveillance just like other institutions, but this feature does not make transparent who is doing what, how they are doing it, and with whom they are doing it. Investor protection is not an issue for many individual unregulated entities to the extent that they restrict their investor base to institutions (pension funds, insurance companies, hedge funds) and wealthy individuals willing to invest with relatively high minimum amounts.

Starting with the collapse of the European exchange rate mechanism (ERM) in 1992-93, intensified during the Asian crises and the financial market disruptions associated with the Russian sovereign default and the collapse of LTCM, and in light of their tremendous growth over the past several years, hedge funds came to be seen by many, correctly or incorrectly, as potentially giving rise to systemic risk concerns. Others believed that the attention paid to hedge funds as posing systemic risks was misplaced and instead should have been focused on the overthe-counter derivatives markets instead (Schinasi et al. 2000). As the recent global crisis demonstrated, hedge funds did not play a (major) role in the virulent market dynamics and dysfunctioning whereas the over-the-counter markets did play a major role.

Global financial markets - a third source of systemic risk identified in the second column of table 2-fall between being and not being regulated and supervised. What is meant by global markets? Examples are the foreign exchange markets and their associated derivatives markets (both exchange traded and over the counter) and the G-3 (dollar, euro, and yen) fixed-income markets as well as others associated with international financial centres (pound, Swiss franc, etc.) and their associated derivatives markets. Dollar, euro, and yen government bonds are traded more or less in a continuous global market and the associated derivatives activities are also global. The primary line of defense is market discipline.

Global markets are only indirectly regulated. They are subject to surveillance of one form or another through private international networks and business-cooperation agreements; information sharing by central banks and supervisory and regulatory authorities; official channels, committees, and working groups; and less directly through IMF multilateral surveillance of global markets. Parts of these markets are linked to national clearance, settlement, and payments infrastructures, so they are also subject to surveillance through these channels. The risks they potentially pose are less of a concern to the extent that the major players in them-the large internationally active banks - are supervised and market disciplined by financial stakeholders. Nevertheless, if there is poor oversight of the major institutions, then these global markets are subject to considerable risks, including a greater likelihood of systemic risk. One

\footnotetext{
${ }^{5}$ These activities are subject to laws against fraud and the general provisions of commercial codes.
} 
obvious example is the global over-the-counter derivatives markets, which are unregulated and which were prior to the crisis (and still now are) subject to little formal oversight except through the regulation and supervision of the institutions that engage in the bulk of these markets' activities.

The fourth and final source of systemic risks identified in table 2 is the policy framework itself, which includes both macroeconomic policies as well as the financial-stability architecture. As will be discussed later, we believe there were mistakes made in many policy areas which either encouraged the behavior that led to systemic risks or directly posed systemic risks as with some aspects of the financial-stability architecture itself.

As noted in row five of table 2, an additional aspect of the policy framework is crisis management and resolution of financial problems once they become systemic. This part of the policy framework entails the following key components: deposit insurance protection to prevent bank runs; appropriate liquidity provision by central banks to keep markets smoothly functioning; lender of last resort operations to prevent market dysfunctioning and illiquid but viable financial institutions from failing; and recapitalisation, restructuring, and resolution mechanisms (private preferred to public) to maintain orderly transitions for institutions that are not viable. As the global crisis revealed, an important missing element of this policy architecture was an effective framework for resolving potential systemic problems experienced by systemically important financial institutions.

\section{What We Know from the Crisis}

Although the global financial crisis has been characterised by some as caused by the US subprime mortgage crisis, the continuing crises in the euro area, and in Europe more generally, suggest that the earlier and ongoing US problems should be seen as symptomatic of an economic and financial environment that encouraged imprudent risk taking, excessive leverage, a worldwide credit boom, and the accumulation of an unsustainable amount of private and public debt. As has been widely discussed, including in the press, many economic and financial factors contributed to the crisis, and we do not need to repeat the long list here. ${ }^{6}$

The relevant observation for the purposes of this paper (and for reforming the global financial architecture) is that the precrisis policy framework and architecture described above failed to prevent and resolve in a cost-effective manner the kind of financial imbalances that ultimately created systemic risks and events that threatened to create a worldwide depression. This framework — created over time primarily by US and European policy architects—relied heavily on achieving and maintaining a balance between market discipline and official oversight, with the objective of providing checks and balances to prevent systemic threats to financial and economic instability.

The balance was wrong. Neither market discipline nor official oversight by national authorities and international institutions such as the IMF and FSF performed its function as intended. Regarding the balance, it was tilted too heavily toward ex ante market discipline, which proved to be elusive until it was too late-at which point the ex post exercise of market disciplining behavior created panic and market dysfunctioning. It also relied too little on official oversight, which failed to foresee the buildup of systemically significant imbalances and

\footnotetext{
${ }^{6}$ There is a wide range of papers expressing a diversity of views. See, for example, Carmassi, Gros, and Micossi (2009); Caprio, Demirgüç-Kunt, and Kane (2009); de Larosière (2009); Gorton (2008 and 2009); Lane and MilesiFeretti (2010); Levine (2009); Obsfeld and Rogoff (2009); Truman (2009); and Visco (2009).
} 
weaknesses; it also failed to deal as effectively as it might (in a least cost manner) with the crisis once it was upon us. For example, in the United States, if Lehman Brothers would have been subject to regulation that included a Federal Deposit Insurance Corporation (FDIC)-type prompt-corrective action procedure, it is arguable that Lehman's bankruptcy could have been avoided. In addition, even if prevention failed, Lehman's ultimate bankruptcy and resolution would have occurred in a less disruptive manner and at lower taxpayer cost. The same arguments apply to the resolution of Fortis in Europe. As these examples suggest, national frameworks for crisis management and resolution also proved to be inadequate for managing and resolving cross-border problems and even some national stability problems.

In summary, the pre-crisis lines of defense against threats to systemic stability proved to be inadequate and were breached most visibly in the European Union and the United States:

- Private risk management and market discipline failed and markets dysfunctioned, the result of a combination of imperfect information, opaque instruments and exposures, poor incentive structures, insufficient capital and liquidity buffers and excessive leverage, inadequate governance/control by top management, insufficient ex ante market discipline, and loss of trust.

- Official supervision failed to promote safety and soundness of systemically important financial institutions (SIFIs).

- Macroeconomic policies contributed to conditions conducive to financial crisis.

- National and global market surveillance failed to identify the buildup of institutional, market, and system-wide financial imbalances with sufficient clarity and rigor to persuade policymakers to take remedial action.

- Pre-crisis central bank and finance ministry tools for addressing liquidity/solvency issues and for restoring market trust and confidence proved to be inadequate and were out of date and out of tune with the fast-paced nature and global reach of 21st century finance.

In line with this assessment-which broadly is conventional wisdom despite important differences of emphasis-reforms are necessary and being considered in a broad range of areas where the global crisis revealed important weaknesses. Many of these areas have been discussed extensively since the onset of the crisis three years ago and officials in the major financial centres and other G-20 countries are actively debating and crafting solutions aimed at dealing with these weaknesses.

\section{Principal Areas where Reforms Are Necessary}

Six broad and closely related and overlapping areas can be indentified that are particularly relevant for considering reforms of the global financial architecture as it impacts the stability of the global financial system.

Regulatory Requirements for Capital, Liquidity, and Leverage and the Potential Benefits/Costs of "Systemic-Risk" Taxes

The global crisis revealed that regulatory requirements for ensuring the safety and soundness of individual financial institutions (or microprudential bank regulations) were inadequate. There are many facets of these requirements that contributed to the buildup of imbalances and risks: (1) Basel II methodologies were flawed in determining capital requirements for both on- and off- 
balance sheet credit exposures; (2) liquidity risks were misunderstood as was private risk management and regulations; (3) leverage limits were either inadequate or unbinding, or in Europe completely absent; and (4) other aspects of national supervisory frameworks and day-today practices were ineffectively applied.

The Basel Committee on Banking Supervision and the Financial Stability Board are considering reforms to deal with the four above-mentioned revealed flaws in the approaches taken to ensure the safety and soundness of institutions. Significant increases in capital, liquidity, and leverage requirements were originally envisioned in a Basel Committee proposal sent out for comment in December 2009.

On July 26, 2010, the Group of Governors and Heads of Supervision-the oversight body of the Basel Committee on Banking Supervision-met to review the Basel Committee's capital and liquidity reform package. Their announcement expressed a deep commitment to increase the quality, quantity, and international consistency of capital, strengthen liquidity standards, discourage excessive leverage and risk taking, and reduce procyclicality. They also announced they had reached broad agreement on the overall design of the capital and liquidity reform package, including the definition of capital, the treatment of counterparty credit risk, the leverage ratio, and the global liquidity standard. Unfortunately, compared to the revisions to Basel II put forward in the December 2009 proposals, the agreement reached in July 2010 provided many concessions favorable to the banking industry, including a less demanding definition of Tier 1 capital, less stringent liquidity requirements, and a lower leverage limit (only 3 percent) phased in over a longer period ending in 2017.

The Group of Governors and Heads of Supervision, the oversight body of the Basel Committee on Banking Supervision, announced on September 12, 2010 a strengthening of capital requirements (Basel III) and it fully endorsed the agreements it reached in July 2010. The Committee agreed a package of reforms that raises the minimum common equity requirement from 2 percent to 4.5 percent and requires banks to hold a capital conservation buffer of 2.5 percent to withstand future periods of stress. This brings the total common equity requirements to 7 percent. The minimum common equity and Tier 1 requirements will be phased in between January 1, 2013 and January 1, 2015, whereas the capital conservation buffer will be phased in between January 1, 2016 and December 31, 2018 becoming fully effective on January 1, 2019. Other more detailed but no less important elements will be phased in by January 1, 2018 - such as the treatment of non-core-equity assets and recapitalisations.

The Basel Committee is planning on supplementing these higher capital requirements with liquidity requirements and leverage restrictions, but they also will be phased in over time. The former comprise a new liquidity coverage ratio (effective 2015) and a revised net stable funding ratio (effective 2018) and the latter a leverage ratio of 3 percent (to be phased in by 2018). The Group of Governors and Heads of Supervision also noted in the September 12 press release that systemically important banks should have loss absorbing capacity beyond the standards announced and that this issue will continue to be addressed as part of the work streams of the Financial Stability Board and the Basel Committee.

Although the agreement announced in September 2010 constitutes progress, it is clear that the Committee could not reach a consensus on earlier implementation of important elements of reform. Capital requirements are raised significantly as agreed by G20 leaders (in 2009), but 
they are not introduced until 2013 and are not completely phased in until 2015. This carries the risk that some banks will continue to be 'undercapitalised' until 2015. Moreover, the Committee could not reach a consensus on implementing other important aspects of the reforms agreed by G20 leaders until 2018 - notably, an increase in liquidity requirements to improve liquidity-risk management and a leverage ratio of 3 percent to reduce the propensity for excessive leverage. That a consensus could not be reached is disappointing: excessive leverage and poor liquidityrisk management by the major global banks played an important role in creating the conditions for the global crisis. They also contributed importantly to the virulent market dynamics and market dysfunctioning that prevailed throughout 2008-09. This mixed record to date by the regulators and supervisors is not reassuring for the prospects to agree on the difficult reform trade-offs and decisions that are yet to be taken and implemented on both sides of the Atlantic, including those pertaining to SIFIs, over-the-counter derivatives markets, and resolution mechanisms for cross-border banking problems.

Authorities in the major financial centres have also been grappling with ways of addressing the systemic nature of nonbank financial institutions after learning that even a relatively small but highly interconnected financial firm like Lehman Brothers could pose a systemic risk to the global financial system and economy. Various taxes, surcharges, and levies on individual SIFIs are being considered to meet a variety of objectives: to pay for past costs of recapitalisation; to set aside "insurance" funds to pay for future problems; and to alter incentives so that excessive risk taking is reduced. A part of the challenge is to develop microprudential measures that can be imposed on those institutions that are deemed to pose systemic risks regardless of their legal and regulatory organisational structure. Earlier the G-20 considered the possibility of a systemic-risk capital surcharge with the aim of imposing a micro level tax on SIFIs to add protection to capture systemic externalities posed by individual institutions. It is not clear whether this idea is still under active consideration.

The US regulatory reform legislation, the Dodd-Frank Act, did not impose an ex ante tax even though at various points in the process the draft legislation anticipated doing so. US financial institutions may be required ex post to repay the FDIC and US Treasury for the fiscal costs of orderly liquidation of a US financial company. The United Kingdom is considering an internationally coordinated systemic risk tax on financial institutions that could help to reduce the risks and impact of future financial crises, and other countries within Europe are also considering levies to deal with future problems. Because finance is fungible and global-as are the relevant institutions-systemic-risk capital charges or taxes are likely to have limited impact in reducing systemic risk if they are imposed unilaterally. Global coordination would enhance the effectiveness of a systemic-risk charge, but the playing field for SIFIs is not level today and is unlikely to be level in the future. It is an unfortunate political reality that international agreements tend at best to produce common minimum standards even when obvious collective solutions can be envisioned and implemented. ${ }^{7}$

\footnotetext{
${ }^{7}$ The G-20 in Toronto (2010, annex II, paragraphs 21-23) endorsed five principles to promote financial sector responsibility via a financial levy. It remains to be seen whether the application of these principles satisfies the fifth, which is to "help provide a level playing field.” Testifying on July 20, 2010 before the Subcommittee on Security and International Trade and Finance of the US Senate Committee on Banking, Housing, and Urban Affairs, US Treasury Under Secretary Lael Brainard and Federal Reserve Board Governor Daniel Tarullo both acknowledged that global convergence may require different approaches across nations and identified aspects of the Dodd-Frank
} 


\section{Perimeters or Boundaries of Financial Regulation, Supervision, and Infrastructures}

The "perimeter" or "boundary" of financial regulations, supervision, and infrastructures proved to be too narrow or ill-defined to prevent systemic problems from arising and worsening. For example, US authorities in charge of managing crises and resolving bank failures had no legal authority or standing in resolving the problems of Bear Stearns and Lehman Brothers. The Federal Reserve was able to help to facilitate an acquisition of Bear Stearns but was unable or unwilling to do so with Lehman Brothers. That was all about firefighting ex post not ex ante. Ex ante, the perimeter problem and challenges are particularly acute for nonbank financial institutions with significant cross-border exposures and businesses.

The boundary or perimeter challenge is multidimensional. The most obvious sources of perimeter or boundary problems are: (1) off-balance sheet activities conducted through over-thecounter derivatives markets and embodied in unregulated special purpose vehicles; (2) the national orientation of prudential oversight despite the existence of systemic cross-border institutions operating in multiple jurisdictions; (3) the banking orientation of supervisory oversight to the exclusion of other systemically important nonbank financial institutions (AIG, Lehman, GE Capital, hedge funds); and (4) many sources of regulatory arbitrage within national financial systems (for example, Basel related off-balance sheet arbitrage of capital requirements) and across geographical as well as legal boundaries.

Key unresolved questions include the following. Can the existing national frameworks be reformed so that they can better anticipate and prevent problems in cross-border institutions? In the transatlantic or global spheres, for example, can international groupings and committee structures be reformed to provide sufficient early warnings? In this regard, are supervisory colleges for cross-border supervision a promising avenue? If not, what steps are necessary to improve global coordination so that more effective prevention and resolution mechanisms are established to deal with problems emanating from any systemic financial institutions regardless of its core franchise? ${ }^{8}$ Can differences in the legal treatment of country bankruptcy be managed short of adopting a uniform approach? How should differences in accounting practices be treated if not harmonised? It is far from clear that the evolving US and EU approaches to these areas are consistent.

\section{Regulation and Surveillance of Global Money and Financial Markets}

Although authorities in all of the major financial centres agree that global money and financial markets, in particular the over-the-counter derivatives markets, need to be effectively regulated and subject to surveillance, creating an effective regulatory framework is likely to pose significant operational and politically contentious challenges. Over-the-counter derivatives markets constitute a global network of counterparty relationships among and between primarily SIFIs - a network in which these institutions act as dealers and market makers, manage financial

Act that are not likely to be embraced outside the United States, including restrictions on proprietary trading, participation in derivatives transactions, and any limits on the size of financial institutions.

${ }^{8}$ Giovannini (2010) examines the "boundary problem” between the financial functions (services) society desires and the set of financial institutions that actually try to deliver them. He observes that the global crisis revealed a "boundary" or "perimeter" mismatch between functions and institutions. He concludes that reforms are necessary to realign financial functions (or services) with the institutions that deliver them so they can be more effectively privately risk managed as well as officially regulated and supervised to prevent systemic problems. 
risks, and trade on their own account (capital). In effect, this network is an extension of the global interbank money market. It is at the core of the global financial system, and it provides "utility" financial services that affect indirectly many aspects of company and household finance. As the global crisis demonstrated, a single credit event or weak link in this network can quickly lead to a systemic problem as SIFIs rebalance and reprice their portfolios to minimise exposures and preserve their own liquidity. When this happens, the network shrinks, becomes fragile, and as we saw in autumn 2008 it ultimately can dysfunction.

The autumn of 2008 was not the first time this network threatened to meltdown. Ten years before, in September 1998, the market turbulence surrounding the collapse of LTCM occurred in this same network; it was a wake-up call that this market was subject to considerable systemic risk. ${ }^{9}$ In the event, as the crisis revealed, many of the counterparty- and liquidity-risk problems that surfaced during the LTCM crisis surfaced again in more dramatic fashion in 200710 and without hedge funds playing a major role. It is at least a reasonable hypothesis that sufficient reforms to counterparty- and liquidity-risk management procedures and practices were not effectively implemented even though the private and official community gathered many times and wrote many reports about what needed to be reformed and how to accomplish it.

Effective and enduring reform efforts in this area will require changes in many dimensions: legal, process, architecture, and cross-border cooperation. Reform proposals across the Atlantic differ, and fierce competition between the major financial centres is active, but there is also much common ground. The OTC money and derivatives markets are truly global and systemic. Uncoordinated solutions risk exacerbating problems, for example a massive shift of these activities to the least regulated and/or weakest oversight jurisdiction with the potential consequence of even greater excessive risk taking, risk concentrations, and excessive leverage. More generally, anything short of a global solution could lead to the persistence of regulatory arbitrage, complexity, opacity, and systemically threatening counterparty relationships. For these reasons, leadership at the head-of-state level may be required to force a consensus that a global regulatory framework and platform is necessary to regulate the activities in these markets and conduct continuous effective surveillance over them.

\section{Systemically Important Financial Institutions or the “Too Big to Fail (TBTF)” Problem ${ }^{10}$}

As touched upon above in the discussion of systemic-risk charges and taxes, the global crisis revealed a fundamental flaw in the precrisis architecture for preventing global financial systemic problems in systemically important financial institutions. Over the years, several reports were written that identified and examined sources of systemic risk, including involving financial institutions, specific markets, and financial infrastructures. ${ }^{11}$ Because of the strong adverse economic impact of the global financial crisis, greater attention is now being paid to these sources of systemic risk - including by the G-20 leaders and the general public at large (taxpayers). Thus, it is now more widely understood that some financial institutions pose risks to the stability of the entire global financial system because of their size, complexity, and interconnectedness.

\footnotetext{
${ }^{9}$ For an extensive discussion of the potential for systemic risk in over-the-counter derivative markets see Schinasi et al. (2000).

${ }^{10}$ The companion paper by Goldstein and Véron (2010) focuses primarily on the TBTF issue.

${ }^{11}$ See, for example, G-10 (Promisel Report, 1992), Schinasi, et al. (2000), and G-10 (2001).
} 
One way of interpreting this heightened recognition is that, prior to the crisis, there was a widespread misunderstanding —an intellectual deficit and even a lack of imagination—about how systemic financial risks and, ultimately, economic instability can be caused by the activities of a single financial institution (a complex financial conglomerate). As observed in Fischer (2009), there is a clear distinction to be made between the recognition of a source of risk, a warning that the risk is growing and becoming systemic, and actually taking action to prevent the risk from being realised. Over the years prior to the crisis, there was much recognition of risks, fewer serious and credible warnings, and very few instances in which strong actions were taken to reduce or avoid the kind of imbalances that led to systemic events.

In this regard, the precrisis architecture for safeguarding global financial stability can be judged to have failed to assess, monitor, and manage the wider implications of financial imbalances and weaknesses that can emerge within individual financial institutions. Simply put, the authorities in charge of safeguarding financial stability fell behind the curve in understanding how to manage the changed nature of systemic risk in a financial system comprising global institutions and market-oriented securitised finance. For lack of a better label, the relevant financial institutions have become known as too big to fail (TBTF). ${ }^{12}$ A more neutral and appropriate phrase — systemically important financial institutions (SIFI)—focuses on systemic importance and downplays the role of any one of the often-mentioned characteristics, such as large, complex, interconnected, unique, etc.

According to a recent Report to G-20 Ministers of Finance and Central Bank Governors (FSB, IMF, and BIS 2009):

"[I]n practice, G-20 members consider an institution, market or instrument as systemic if its failure or malfunction causes widespread distress, either as a direct impact or as a trigger for broader contagion. The interpretation, however, is nuanced in that some authorities focus on the impact on the financial system, while others consider the ultimate impact on the real economy as key." This specific language reflects both the difficulty of defining systemic importance and of reaching a consensus among G-20 finance ministers and central bank governors. ${ }^{13}$

Nevertheless, other authors have been less shy and reserved in trying to define SIFI. ${ }^{14}$ Drawing on these other suggestions, the following factors either alone or in combination could render individual financial institutions as systemically important:

- size relative to the economy, key markets, or other like institutions;

- scope of activities;

- complexity of business model, organisation, and risk-taking activities;

- opacity of the nature and magnitude of risk exposures;

- interconnectedness of activities with other financial institutions, markets, and infrastructures;

- similarity (or correlation with) of activities and risk exposures to other institutions; and/or

\footnotetext{
${ }^{12}$ In normal circumstances, a financial institution like Northern Rock would not be considered a systemically important financial institution. It became systemic because of the specific circumstances and situation that evolved in the United Kingdom. Thus, as is discussed later, systemic importance is not just a matter of size, complexity, or interconnectedness; it is also situational, state dependent, and time varying.

13 The FSF identified 30 or so large complex financial institutions that were considered to merit, and now have, core supervisory colleges and standing cross-border crisis management groups. For the presumptive list of these entities — which has not been made available to the public at large—see Jenkins and Davies (2009).

${ }^{14}$ See Thompson (2009); US Treasury (2009); Brunnermeier et al. (2009); and ECB (2006, 2007, and 2008).
} 
- nonsubstitutable, systemically important activity.

Other factors could be relevant as well, including the macroeconomic and macrofinancial environment. Thus, whether an institution is an SIFI depends in part on its structure as well as economic and financial conditions beyond its control. In other words, the definition itself is "state contingent" and "time varying" to some degree.

Regardless of the nomenclature, several global financial conglomerates were both the cause and consequence of the systemic risks and events they collectively helped to create. In the event, the activities of Bear Stearns, Lehman, and AIG (to name a few) helped to create the complex network of counterparty relationships that ultimately became unsustainable, unraveled, and caused repeated episodes of market panic and the dysfunctioning of the global financial system. Many other large, global financial institutions that were not merged or did not fail also contributed to the buildup of excessive risk taking and leverage prior to the crisis, but they too required unprecedented remedial actions individually and collectively. The remaining global institutions now compose a more highly concentrated network of counterparty relationships within the core of the global financial system than before the crisis. In other words, the restructurings and bankruptcies of several global financial institutions have created a more highly concentrated global financial system. It is not unreasonable to think that the systemic risks associated with the activities of the remaining global institutions have gone up because of this restructuring and the manner of its financing.

It is reasonable to conclude from the crisis that precrisis banking regulations, supervisory frameworks/practices, and market surveillance did not just fail but were in fact incapable of assessing, monitoring, and supervising the risk profiles of global institutions and the implications for global financial systemic stability both prior to and during the early stages of the crisis. The inadequacy of the global financial architecture for dealing with these institutions and their roles in global markets shaped importantly the policy responses. Responses entailed unprecedented public credit guarantees, unprecedented recapitalisations, forced restructurings with public guarantees and ownership, and perhaps unprecedented and still extant moral hazard.

An additional problem revealed by the crisis is that government efforts to recapitalise cross-border institutions (for example, Lehman Brothers) reverted immediately to national ringfencing and solutions - which exacerbated market panic and systemic problems. Even in the case of Fortis in Europe, for which it can be argued that excellent preconditions for coordinating a rescue existed between Belgium, Luxembourg, and the Netherlands, the financial resolution ultimately devolved to each country ring-fencing and recapitalising the domestic pieces of the pan-European institution.

Our takeaway is that reforms are necessary in many related areas pertaining to SIFIs if systemic risk management is to be improved significantly in the future. These areas include regulation, supervision, market surveillance, crisis management, rescue, and resolution. Some reformers have advocated breaking up these institutions into more transparent, focused, and specialised institutions that are easier to regulate, supervise, rescue, or resolve. But, whatever its merits, the political will does not exist to consider this approach seriously. Short of this more surgical approach, reforms will have at least to recalibrate the balance between the private benefits and potential social costs of SIFIs in providing financial services in our modern financial system and the best way to risk-manage their delivery. ${ }^{15}$

\footnotetext{
${ }^{15}$ See FSB, IMF, and BIS (2009) and FSB (2010).
} 


\section{Crisis Management, Rescue, and Resolution}

Much of the reform agenda has focused appropriately on improving the architecture's ability to prevent the next crisis. For example, the creation of a US Financial Stability Oversight Council and a European Systemic Risk Board are necessary and worthwhile efforts aimed at improving the ability to assess the potential for systemic risk in the absence of market pressures and adequate supervision and regulation. Early detection of financial imbalances is necessary to avoid systemic problems through the implementation of risk-mitigating measures that could reduce the potential for financial imbalances becoming systemic and threatening financial stability. Authorities on both sides of the Atlantic are proposing to devote considerable resources and political capital to improve early warning systems to the point where they become more reliable.

However, authorities should have realistic expectations about whether these early warning systems will be effective. The reality is that crises will occur again. The crucial question is whether warnings will lead to action.

The costly and ad hoc rescue and resolution efforts of authorities during the global crisis provide clear evidence that countries generally lack effective mechanisms for managing, rescuing, and resolving weak or insolvent financial institutions with significant cross border exposures, including SIFIs, in a cost effective manner. These widespread challenges were apparent in dealing with national, continental, and global financial institutions and markets.

The challenge for all of the major financial centres is to establish legally robust, operationally practical, and compatible frameworks designed for the orderly resolution of systemically important financial institutions in a timely manner and with the capacity to minimise both the systemic consequences and taxpayer costs of resolution. Solutions are being pursued on both sides of the Atlantic, but the outcomes are likely to be less coordinated and compatible than is desirable for resolving cross-border institutions operating in several legal jurisdictions.

In addition to rescue and resolution, the crisis also revealed weaknesses in the ability to manage and to resolve liquidity problems associated with financial distress and instability. Notably the European Central Bank, the Bank of England, and the US Federal Reserve all lacked established instruments to resolve liquidity problems and needed to innovate and introduce new ways of operating in the markets with financial institutions to maintain monetary stability in the presence of financial instability. In effect, prior to the crisis, the major central banks all fell behind the curve in understanding the liquidity-hungry nature of securitised markets and the changed nature and greater market orientation of systemic risk, including their global scope (Schinasi 2009c). Many policy issues need to be addressed to improve the ability of central banks to manage future crises. In the area of prudential oversight, two particular issues stand out.

- Central bank mandates for prudential supervision in all of the transatlantic financial centres fell short of what was required to prevent financial problems from becoming systemic and for dealing with the crisis once it was systemic. In the United States, the Federal Reserve did not have oversight responsibilities for all of the SIFIs operating in US markets as some of them were investment banks and insurance companies. In the United Kingdom, the Bank of England had responsibility for financial-market stability but did not have responsibility for banking supervision and had to rely on cooperation with the UK Financial Services Authority (FSA), an arrangement that proved to be ineffective. In the euro area, while some national central banks within 
the European System of Central Banks (ESCB) have supervisory powers, the European Central Bank (ECB) itself had no formal responsibility for supervision.

- The relevant authorities had neither the comprehensive power to obtain relevant timely information from all SIFIs and other unregulated financial institutions nor the authority to intervene (place in administration, liquidate, resolve) SIFIs when it was necessary.

\section{Effective Management of Volatile Capital Flows}

The epicentre of the global crisis of 2007-10 was the US financial system and economy and the principal locus of secondary eruptions was Western Europe. But the crisis became global, encompassing Central and Eastern Europe, Latin America, Asia, and Africa before running its course. A major transmission mechanism was the global financial system and associated capital flows, which dried up, first, for Iceland and Eastern Europe and ultimately for many of the major emerging-market economies, for example Korea. A second transmission mechanism was the recession in the advanced countries that led to a collapse in global trade that was unprecedented in the post-World War II era. ${ }^{16}$

As is documented in Blanchard and Milesi-Ferretti (2009), the major portion of the precrisis gross capital flows involved the advanced countries, primarily of the North Atlantic. The emerging market economies were the source of net capital flows. In the case of the Eastern European countries, net and gross capital flows financed large current account deficits. However, the emerging market economies of Asia and Latin America, in particular, were also recipients of substantial gross capital flows. Korea is exhibit number 1.

Korea had the fifth largest foreign exchange reserves as of February 2008 and ran substantial cumulative current account surpluses during the years in advance of the crisis (Truman 2009). Nevertheless, it was hit hard by a reversal of the gross inflows of capital to Korea that were a feature of the immediately preceding years. One consequence was the Bank of Korea took advantage of the Federal Reserve's offer to open a \$30 billion swap line that the bank could use to support financial institutions needing to repay US dollar borrowings. The Federal Reserve opened similar lines with the central banks of Brazil, Mexico, and Singapore. ${ }^{17}$ Mexico along with Colombia and Poland also took advantage of the flexible credit line (FCL) put in place by the IMF in March of 2009.

In the aftermath of the global crisis, as many emerging-market countries have recovered more rapidly than the advanced countries causing some of their central banks to raise their official interest rates, global capital flows have reemerged as a problem for some countries. A few have instituted controls to impede the inflow of capital.

Unwanted capital flows are generally a problem both in the management of macroeconomic policies and in safeguarding the stability of domestic financial systems, which are the normal, but not necessarily the only, conduit for such flows. ${ }^{18}$ Moreover, with the globalisation of the financial system, capital flows are likely to continue to be a source of concern even without crises on the scale of that of 2007-10. Thus, the effective management of

\footnotetext{
${ }^{16}$ See IMF (2010b), Herman and Mihaljek (2010), and McGuire and von Peter (2009).

${ }^{17}$ In addition to the Bank of Korea, the Bank of Mexico drew on its line, but the Central Bank of Brazil and the Monetary Authority of Singapore did not.

${ }^{18}$ Roberto Zahler (2010) emphasizes that short-term capital inflows can go directly to equity markets or to nonfinancial borrowers bypassing domestic financial institutions.
} 
such flows is a key challenge in ensuring financial stability and for macroeconomic policies. Reasonable responses to such flows require cooperation both by source and recipient countries involving both prudential and macroprudential policies (Truman 2010a).

This is an area where representatives of both the European Union and the United States have reservations. The United States appears to be more receptive to expanding the IMF's lending facilities, and the Europeans appear to be less so even though a number of countries in the European Union, and now the euro area have taken advantage of the increased flexibility of the IMF's lending operations. As of this writing, Europeans are resisting a substantial increase in the IMF's quota resources, which would be necessary if the IMF were to play an expanded role as a lender of last resort. The US position is one of skepticism, yet to be convinced. The views of both on the use of controls on capital inflows appear to have mellowed since the late 1990s. A reasonable guess, however, is that neither is prepared openly to embrace the view that its own macroeconomic, in particular monetary, policies should or might need be altered in light of trends in capital movements.

\section{The IMF and Financial Stability Board Today}

Against the background of the previous section outlining the principal areas where reforms are necessary, this section examines the IMF and the FSB, the principal international institutions responsible for the GFS in the postcrisis environment. We examine five aspects of those institutions: membership and representation; tools and instruments; compliance and leverage; macroprudential orientation; and accountability and transparency.

\section{The International Monetary Fund}

The IMF commenced operations in 1945-65 years ago. Its objectives were then, and remain today, to promote growth and financial stability via its lending and surveillance activities and a variety of mechanisms in support of international cooperation. At the start, the IMF's role was focused on exchange rate stability and the removal of restrictions on payments that limited the expansion of international trade.

The IMF's primary focus was on the international monetary system and the Bretton Woods regime of fixed, but occasionally adjustable, exchange rates. Indeed, the purposes of the IMF stated in Article I of the Articles of Agreement as they stand today focus on the promotion of "international monetary cooperation. . . [and] the machinery for consultation and collaboration on international monetary problems.” In the period immediately after World War II and continuing into the 1960s when the Bretton Woods exchange rate regime came under pressure, the private sector's role in the global financial system was largely ignored. The international monetary system was the entire GFS as we defined that term earlier. Even today, Article VII limits the use of the IMF's resources to make capital transfers. The only limitation on the use of capital controls is that they should not be used to impede trade and current account transactions.

The expansion of private capital flows in the 1960s was one of the many contributing factors to the demise of the Bretton Woods system. Some thought that with the passing of fixed exchange rates among the currencies of the major countries, which were then the currencies of the G-10 countries; ${ }^{19}$ the IMF would and should go out of business. These hopes or fears did not

\footnotetext{
${ }^{19}$ The 11 G-10 countries are Belgium, Canada, France, Germany, Italy, Japan, the Netherlands, Sweden, Switzerland, the United Kingdom, and the United States.
} 
materialise. The members of the IMF supported the evolution of the institution in the context of the oil shocks and inflationary chaos of the 1970s, the global debt crisis of the 1980s, the challenges of transition economies in the 1990s, the debt crises of the mid and late 1990s, and more recently the global economic and financial crisis of 2007-10 (Truman 2006b, 2008, and 2010b).

As time passed the attention of the IMF and its members turned increasingly away from the structure and functioning of the international monetary system and arrangements among governments toward the global financial system. This was most vividly illustrated by the IMF's involvement in capital account financial crises of the 1990s. Since 2001, the IMF has published its Global Financial Stability Report (GFSR), first as a quarterly publication and subsequently as a semiannual publication updated quarterly. The GFSR was preceded in the 1980s and 1990s by the annual International Capital Markets reports, which focused on sources of vulnerabilities in international capital markets, and evolved in response to the global debt crises in the earlier decade and in response to subsequent periods of turbulence and crisis throughout the 1990s. Thus IMF staff, management, and membership have engaged in one or another systematic form of assessments or surveillance of global financial system vulnerability for more than three decades.

Nevertheless the IMF (management and staff) did not warn about the impending global economic and financial crisis although some of its various papers and reports identified some red flags. In that sense, its value added to the Global Assessment of Functioning (GAF) was limited.

In the remainder of this subsection, we discuss various aspects of the IMF's evolving role in the global financial system.

\section{Membership and Representation}

The IMF with its 187 member countries is essentially a universal international organisation. In principle, it is fully representative because each member country is directly or indirectly represented on its Board of Governors (see table 1).

However, the Fund departs from the principle of one nation, one vote because the preponderance of its formal decisions are taken by weighted majorities, based largely on IMF quotas, in which each country's voting power is based broadly on its economic importance. Currently, those weights are considered by many observers to be unrepresentative (Bryant 2010).

In addition, and partly as a consequence, representation on the 24-person IMF executive board, its day-to-day decision-making body, is heavily influenced by the 8 to 10 chairs held by European countries as well as by the United States. ${ }^{20}$ With a very few exceptions, the executive directors and their alternates, their advisors, and their staffs are drawn from finance ministries, rather than central banks, and only by coincidence would they include anyone with supervisory or regulatory experience.

\footnotetext{
${ }^{20}$ The countries with the five largest IMF quotas are each entitled to appoint an executive director. The remaining 19 executive directors are elected by constituencies; currently three are one-country constituencies (China, Russia, and Saudi Arabia). The countries In the European Union are spread across 10 appointed executive directors and elected directors of constituencies, which include nonmembers of the European Union, in principle each of those chairs could be occupied by an EU representative. Switzerland is one of those constituencies and heads its own constituency. In addition, the European Central Bank may be separately represented at some meetings of the executive board (Truman 2006a). This European dominance is likely to be reduced somewhat with the election of a new executive board that is scheduled to take over on November 1, 2010.
} 
Thus, the IMF, in principle, is representative, but the structure of its current representation both in terms of voting shares and talking chairs has undercut its legitimacy in the sense, following John Locke, that all countries are members and have representatives in Washington. ${ }^{21}$ However, in the view of some, IMF representation is deficient and consent of the governed is incomplete or blunted. It remains to be seen whether this situation will be substantially changed as the result of agreements reached at the Seoul G-20 summit in November 2010.

\section{Tools and Instruments}

The IMF has a range of tools and instruments that it can employ to help it achieve its objectives: lending, surveillance, analytical studies, and technical assistance.

Although IMF lending operations normally absorb less than one-quarter of IMF administrative expenses, they attract a disproportionate share of attention. The IMF directly impacts the policies of its members primarily via its lending programmes, imposing conditions designed to get out of current crises and to reduce the probability of future crises.

IMF lending, built up to more than $\$ 100$ billion in credit and commitments outstanding in the early 2000s, was back down to about $\$ 10$ billion in September 2008, at the end of the first year of the financial crisis, and subsequently expanded to more than $\$ 200$ billion. This was accompanied by a substantial addition to the IMF's resources, principally via ad hoc borrowing from individual members and, potentially, from an expansion of the New Arrangements to Borrow to $\$ 550$ billion to supplement its usable quota resources of about $\$ 250$ billion. $^{22}$

IMF surveillance over members’ policies and the global economic and financial environment has increased in importance in recent decades. These activities include bilateral surveillance focused on the economic and increasingly the financial policies of individual countries in the form of mandatory Article IV reviews at 12- to 18-month intervals and since 1999 its voluntary reviews under the Financial Sector Assessment Programme (FSAP). ${ }^{23}$ IMF surveillance also has its global component-multilateral surveillance-in the form of executive board discussions and conclusions based on reports on the economic outlook and financial system prepared by the staff. The World Economic Outlook (WEO) was first published semiannually in 1980, and quarterly updates are now issued (Hacche 2009).

The IMF executive board experimented with a multilateral consultation with China, the euro area, Japan, Saudi Arabia, and the United States on global imbalances in 2006-07. It did not have a great impact because the countries participating did not want to commit to any new policy measures and the topic of global imbalances was soon overwhelmed by the economic and financial crisis. ${ }^{24}$ At the time, it was mooted that the next such consultation exercise would involve the global financial system issues, but that intention was displaced by the crisis.

\footnotetext{
${ }^{21}$ We use the word "legitimacy" as it is used in the literature on political theory. For example, according to John Locke (see Ashcraft 1991, page 524), "The argument of the [Second] Treatise is that the government is not legitimate unless it is carried on with the consent of the governed."

${ }^{22}$ The allocation of about $\$ 280$ billion in special drawing rights (SDRs) by the IMF directly augmented the resources of member countries to deal with the consequences of the crisis.

${ }^{23}$ The World Bank participates in FSAPs for developing countries. In the case of both institutions, the staff conducting the reviews are largely seconded from national authorities because the Fund and the Bank lack the staff and other resources to do the work in house.

${ }^{24}$ An active minority of observers think that global imbalances played a major role in precipitating the 2007-10 crisis, but that is not our view.
} 
The IMF's analytical multilateral surveillance publications such as the WEO and GFSR and their predecessors and an array of working papers, staff position notes, and other documents are an important tool by which the IMF staff of close to 3,000 with the support, and in some cases instigation, of IMF management (the managing director and the three deputy managing directors) attempt to influence the policies of its members and shape debates about current policy issues and challenges.

The IMF's technical assistance programmes offer another mechanism through which the IMF can promote and support better policies, including policies of member countries in the financial area. Those policies contribute to financial stability in the financial systems of the individual countries and in the aggregate stability of the system as a whole, but they are not at the core of issues confronting the architecture of the global financial system today as we outlined earlier.

\section{Compliance and Leverage}

The IMF is not constituted to be a rigorous international regulator. The formal obligations of members under the IMF Articles of Agreement are few, and many of those obligations are honored in the breach. Based on this reality, Truman (2010b, page 38) argues that the IMF's regulatory role "is considerably broader in practice than that of a regulator in the national context, but that role is dependent on the mutual consent of governments initially to agree to subject themselves individually to the IMF's oversight and subsequently to adjust their policies in response to that oversight. The oversight or regulatory role to a substantial degree is enforced via the self-application by its members of peer review processes."

The IMF does have considerable leverage over countries that require financial assistance in support of recovery and reform programmes, and the Fund has used that leverage effectively. We would submit that the record of increased financial stability in recent years among Latin American, Asian, and African countries owes substantially to reforms encouraged by the IMF in connection with reform programmes of those countries that were supported by IMF financial assistance as well as by the World Bank and other development banks. ${ }^{25}$ When not linked to IMF lending operations, the IMF can only assist those countries that want to be assisted.

Finally the IMF, by virtue of the size, range of skills, and relative independence of its professional staff and management, can influence and exert leverage over the policies of member countries via use of the bully pulpit backed by robust analysis. ${ }^{26}$ Many observers note the

\footnotetext{
${ }^{25}$ This is the principal conclusion in IMF (2010b, page 4) emerging-market "countries that had improved policy fundamentals and reduced vulnerabilities in the precrisis period reaped the benefits of these reforms during the crisis.”

${ }^{26}$ We use the phrase professional staff to mean a staff whose primary objective is to use its skills, training, experience, and expertise to help the organization achieve its mandate largely free from the political influence or policy preferences of member countries and organizations. By independence we mean a staff that is largely free to exercise, express, and publish its professional judgments and opinions without the political and policy influence of member countries and organizations. Article VII, section 4(c) states, "The Managing Director and the staff of the Fund, in the discharge of their functions, shall owe their duty entirely to the Fund and to no other authority. Each member of the Fund shall respect the international character of this duty and shall refrain from all attempts to influence any of the staff in the discharge of these functions.” In practice, IMF staff are encouraged to express their professional judgment and personal views in several publications, including IMF working papers, occasional papers, and staff position notes. The World Economic Outlook and Global Financial Stability Report are documents of the staff in which a disclaimer notes that the views expressed are those of the authors and not those of IMF management or its executive board. A majority of IMF economists are hired directly from graduate schools; some are hired and
} 
important role of the IMF staff and management as "trusted advisors.” This role sometimes comes in conflict with "name and shame" efforts to exert influence over the policies of members to bring them into better compliance with global norms and standards. However, the resistant or recalcitrant country is free to ignore the advice and entreaties of the IMF staff, and even to deny information to the IMF, unless the country requires financial support from the IMF or its blessing to receive financial support from the private sector. Moreover, messages from the management and staff of the IMF are often diluted by the softer messages from the more political executive board.

The IMF's representation issues that affect its legitimacy, in turn, weaken its leverage including via peer review processes. In addition, the extent of leverage the IMF management and staff have over the largest member countries-once the G-7 countries and now a longer list — can be questioned. It depends in part on the governance processes in those countries and the role of the media and interest groups as well.

\section{Macroprudential Orientation}

The IMF is the premier international organisation when it comes to the analysis and assessment of macroeconomic policies. The IMF does not have a monopoly on these issues among international organisations, but its mandate and near-universal membership guarantee the IMF the widest scope and respect. ${ }^{27}$ As noted above, the IMF has engaged in capital markets and global financial system surveillance since the 1980s and has published numerous, regular reports since then. It has a large staff focusing on the multilateral issues, and its bilateral country surveillance has been refocused toward a more macrofinancial orientation as an additional pillar to supplement bilateral surveillance work on macroeconomics and monetary, fiscal, and exchange rate policies.

On the other hand, since the collapse of the Bretton Woods exchange rate regime, the IMF's governance has become increasingly dominated by finance ministries and increasingly distrusted, partly as a consequence, by central banks. Moreover, the finance ministry representation on the executive board and among the deputies of the International Monetary and Financial Committee (IMFC) — that is, below the level of the ministers and governors—is by individuals with experience and skills in international affairs but not necessarily macroeconomic affairs. Thus, the expertise of the IMF staff is disconnected from formal interaction with the relevant macroeconomic and also supervisory authorities by virtue of the IMF's governance structure.

The national authorities, in turn, are to varying degrees engaged in system-wide financial surveillance activity as well, in the form of financial stability reports. However, these reports are largely focused on national (or regional) markets and priorities except to the extent that the global environment impinges on them. Many of the financial stability reports set the stage for risk assessments by surveying the global financial landscape as it relates to conditions and risks in national markets, financial institutions, and infrastructure. However, they are drafted primarily

\footnotetext{
sometimes seconded for a limited term from national authorities. The IMF website provides disclosures on professional requirements, salaries, benefits and other staff related information.

${ }^{27}$ Among the competing international organizations are the World Bank (equally universal but with a different mandate), the Organization for Economic Cooperation and Development (more limited membership), and the Bank for International Settlements (more limited membership and a more limited mandate).
} 
by central banks with some input from national supervisory authorities, and the IMF itself has limited interactions with these groups. ${ }^{28}$

\section{Accountability and Transparency}

The IMF is viewed by many private sector observers as opaque and mysterious, and some see it as conspiratorial if not malevolent. The IMF has a formal anchor in its establishment by an international agreement that was ratified by its member governments, clearly establishing its governance if not its broader governmental processes. Because the IMF is an inter-governmental organisation, it can operate above the political processes that affect its member governments. If a substantial majority of them are satisfied with the IMF's work, the institution is largely protected from outside pressures and criticisms.

However, as noted above, some member governments question the IMF's legitimacy. Moreover, the legitimacy of some of the member governments is questioned by the nongovernmental organisation (NGO) community. They also criticise the Fund for a lack of accountability and transparency. Thus, the IMF faces its own issues in this area along with the associated questions of access to its decision-making processes and transparency about those processes. As a formal matter, IMF transparency about its official business, for example minutes of executive board discussions, is controlled by its members through the executive board. The management and staff, responding to the increased pressures for accountability and transparency from 21st public opinion have carved out some scope to act informally and independently of the board via papers and web postings.

\section{The Financial Stability Board}

The Financial Stability Forum - the forerunner to the Financial Stability Board — was established by the G-7 countries in February 1999 in the aftermath of the Asian financial crises, the Russian default, and the financial turmoil that accompanied the demise of the hedge fund Long-Term Capital Management (see box 1-Brief History of the FSF). It was created and structured to coordinate, not to act.

The FSF's secretariat was small. Aside from those activities directed at identifying vulnerabilities and gaps in policy with associated recommendations to fill the gaps, the bulk of the substantive work was produced by committees composed of and chaired by FSF members. The reports issued were high quality consensus documents focusing on a few key issues. After the first burst of reports in the 2000-2002 period, the FSF largely settled into a role of trying to identify incipient national and international financial vulnerabilities and the review of reports from other bodies. ${ }^{29}$

During its tenure, the FSF coordinated work in developing and disseminating standards and codes and best practices in regulation and supervision of finance in concert with the international standard setters and the IMF and World Bank. It served as a useful forum for member countries, international financial institutions, and standard-setting bodies to share

\footnotetext{
${ }^{28}$ In the future, the United States will be an exception to this generalization. The US Treasury will have responsibility for financial stability reporting on behalf of the Financial Stability Oversight Council.

${ }^{29}$ In an initial burst of activity in its first two years, the FSF sponsored working groups on highly leveraged institutions (hedge funds), capital flows, and off-shore financial centres. However, responding to the wishes of the United States and other G-7 countries, it subsequently took fewer such initiatives (Helleiner 2010).
} 
information and analyses and learn from each other, which was one of its principal purposes. It created opportunities to address many of the externalities that exist in finance (information asymmetries, for example, within the context of the vulnerabilities discussions) and that posed risks to the global financial system. Public-good benefits were captured as a result of the work of the FSF and the resulting learning by its members with implications for the work under their own remits.

The FSF, as a collective of countries and organisations, identified some risks that were later proved to be central to the global economic and financial crisis. In particular, the FSF starting in 2003 encouraged the Joint Forum in its work on the issue of credit risk transfer activities. ${ }^{30}$ However, insufficient action was taken by member countries in light of the Joint Forum's work. More broadly, the FSF membership included all of the suspect jurisdictions with respect to the global crisis and they did not act sufficiently forcefully, either independently or collectively in advance of the crisis.

It is therefore reasonable to question the value added of the FSF's work during the period prior to the global crisis in which systemic risks and vulnerabilities were accumulating. Notably, the FSF (as a collective organisation) can reasonably be viewed as having been unsuccessful both in terms of developing and implementing supervisory and regulatory standards to prevent a global systemic risks and in terms of developing a collective process accurately to identify and assess sources of global systemic risks and vulnerabilities. In addition, it is notable that the political authorities of non-members were critical of the FSF's limited size and coverage of issues prior to the crisis.

By contrast, once the crisis broke, the FSF produced what many observers regard as an excellent report in early April 2008 (FSB 2008) on enhancing market and institutional resilience. This report laid much of the groundwork for subsequent reforms endorsed and instigated by the G-20 leaders who did not assemble until November that year.

Partly as a consequence, in the heat of the global crisis, the leaders of the G-20 countries in November 2008 called for a larger membership of the FSF. A broad consensus emerged in the following months toward placing the FSF on stronger institutional ground with an expanded membership - to strengthen its effectiveness as a mechanism for national authorities, standard setting bodies (SSBs) and international financial institutions to address vulnerabilities and to develop and implement strong regulatory, supervisory and other policies in the interest of financial stability. As announced at the G-20 Leaders London Summit on April 2, 2009, the expanded FSF was reestablished as the Financial Stability Board (FSB) with a broadened mandate to promote financial stability. The FSB's broadened mandate made mandatory its members' compliance with IMF/World Bank FSAPs and Reports on the Observance of Standards and Codes (ROSCs) and made more explicit and comprehensive its focus on macroprudential work in cooperation with the IMF (see box 2-Mandate of the FSB and table 3).

US Treasury Secretary Timothy Geithner (2009) has argued that the enlarged FSB with expanded powers is now the fourth pillar of global economic governance along with the IMF, World Bank, and World Trade Organisation. The discussion of the FSB that immediately follows, and implicitly this paper as a whole, examines that proposition. We conclude that this characterisation of the FSF is not useful.

\footnotetext{
${ }^{30}$ The Joint Forum includes the Basel Committee on Banking Supervision, the International Organization of Securities Commissions, and the International Association of Insurance Supervisors.
} 
Article I of the FSB's charter (FSB 2009) spells out the objectives envisioned by the Heads of State of the G-20 countries: "The Financial Stability Board (FSB) is established to coordinate at the international level the work of national financial authorities and international standard setting bodies (SSBs) in order to develop and promote the implementation of effective regulatory, supervisory and other financial sector policies. In collaboration with the international financial institutions, the FSB will address vulnerabilities affecting financial systems in the interest of global financial stability."

As envisioned in the FSB's charter, the FSB plenary is the FSB's governing and decision-making body; a steering committee is its co-coordinating body; and there are three operational standing committees addressing vulnerabilities assessment, supervisory and regulatory policies and coordination, and standards implementation. The FSB has an explicit mandate to assess and act on vulnerabilities. The FSB is in a position to draw on the best analysis available globally, and it has a highly professional staff running the secretariat.

The FSB chairman and secretariat acting together are coordinators. Box 3 summarises the role of the FSB chairman. The FSB has neither an explicit policy mandate nor the critical mass of professional staff that would be necessary to engage in analytical studies and independent assessments of global financial vulnerabilities. ${ }^{31}$ But it can draw on the work and resources of the international financial institutions to do so. The FSB secretariat very capably convenes meetings, organises agendas, and manages the processes that produce multinational reports on issues pertaining to its financial-stability mandate (see box 4-Role of the FSB secretariat). The key exceptions to these generalisations are its work on risks and vulnerabilities in the global financial system, which it does jointly with the IMF, and the commitments of its members to participate in peer-review processes within the FSB "framework for strengthening adherence to international standards.",32

\section{Membership and Representation}

The FSF's initial membership was confined to the G-7 countries, international financial institutions, and the international standard-setting bodies. Later in 1999, the FSF membership was expanded to include representatives of four important financial centres: Australia, Hong Kong, the Netherlands, and Singapore; Switzerland was invited to join in 2007 (see table 3Evolution of Membership and Representation of the FSF and FSB). This limited membership on the FSF and the Basel Committee on Banking Supervision (BCBS), the principal standardsetting body (SSB) associated with the FSF, contributed to the perception that there are "rule makers" (the G-7 and the FSF structure) and "rule takers" (the rest of the world).

This perception was ameliorated only in part by the FSF's regional meetings. There were five in 2001-02, but they tapered off to only six over the following four and a half years to mid-

\footnotetext{
${ }^{31}$ Article 15 of the FSB's Charter spells out the role of the secretariat, but neither the charter nor the FSB website provides information about the professional status or independence of the staff of the secretariat. Our understanding is that except for the secretary general and some secretarial and administrative staff, the "professional" staff of the FSB are seconded from and paid by member organizations.

${ }^{32}$ The first such thematic peer review completed in March 2010 focused on the application of standards for sound compensation practices and their implementation. The second will examine implementation of recommendations on risk disclosures in light of the 2008 FSB report on enhancing market and institutional resilience. The FSB is also scheduled in 2010 to conduct country peer reviews of Italy, Mexico, and Spain based on their recent IMF-World Bank FSAPs.
} 
2007 before the start of the crisis. ${ }^{33}$ The fact that the crisis was a G-7-centred affair that also affected many other countries only strengthened the view of outsiders that the FSF and SSBs had paid too much attention to non-member jurisdictions and not enough to monitoring internal problems and issues in member jurisdictions. Thus, as with the IMF and considerably more so, the FSF had, and the FSF still has, a legitimacy problem in the sense of John Locke (see footnote 21).

As noted above, partly in response to these criticisms, the FSB's country membership has been expanded to include all of the G-20 countries and also includes the European Commission. This expansion of membership should improve the coverage of issues by giving a potential voice to emerging-market country issues, needs, and concerns. It could also help to improve compliance with international standards, codes, and best practices in financial regulations and supervision. To the extent that continental/regional membership and representation within the FSB has been expanded and improved, this could help to improve the perceived legitimacy of the FSB with respect to standards and best practices for global finance.

Having said this, the membership is still skewed toward the G-7 countries and geographically towards Europe. The G-7 countries still have 21 of the 52 seats in the 67-seat FSB occupied by country representatives, and European countries occupy 20 of the 54 country seats, including the seats of the European Commission and the European Central Bank for this purpose. Although membership has been expanded to include most, if not all, of the systemically important emerging-market countries, it gives the greatest representation, and therefore potential voice, to the larger countries that are aspiring quickly to enter the realm of advanced countries.

One can argue that adding the voice and perspectives of China and the other systemically important emerging-market countries under the umbrella of the FSB is the key innovation. However, looking at the specifics, while the G-7 countries, Brazil, China, India, and Russia each have three representatives within the FSB, Australia, Mexico, the Netherlands, Spain, South Korea, and Switzerland each have two representatives and Argentina, Hong Kong, Indonesia, Singapore, Saudi Arabia, South Africa, and Turkey each have only one representative. The FSB operates by consensus and in this type of body, the number of voices matters.

Thus, the limited and skewed country and geographic membership of the FSB and the country representation within it will most likely continue to have implications for perceptions about the political legitimacy of the FSB. Perceptions often shape outcomes.

\section{Tools and Instruments}

The FSB does not have policy tools or instruments beyond its mandate to promote collaboration and coordination among its constituent members and to identify gaps and financial system vulnerabilities.

The FSB has a small professional secretariat largely drawn from its member institutions. The secretariat is not designed or intended to conduct independent studies of key issues (see box 4). The FSB relies on FSB member countries, member organisations, and member international financial institutions with their substantial resources to carry out the mission of the FSB. This institutional arrangement places much of the initiative and analytical firepower with those who have national or organisational priorities and political imperatives with their own constituencies. This poses a risk that the national authorities from the larger countries-who also influence the

\footnotetext{
${ }^{33}$ In some sense, the role of the IMF and the World Bank representatives in the FSF was to "represent" nonmembers, but that view has been put forward with respect to the IMF and the G-7 and has not been very convincing.
} 
work programmes of non-country members of the FSB-will continue to shape the FSB's agenda and consensus to their advantage, which could be detrimental to collective action in the interest of global economic and financial stability.

\section{Compliance and Leverage}

FSF member country compliance with international standards and best practices was voluntary, which was perceived by some at the start as a weakness. This structure was a compromise. In 1999, there was no appetite as there is none now for a global regulator or supervisor. The FSF structure comprised three related elements targeted on improving global financial stability: voluntary IMF/World Bank financial-sector surveillance in the form of FSAPs and ROSCs; market pressure/discipline to encourage adherence to international standards and best practices; and a formal process of "name and shame," and possibly sanctions, for offshore financial centres (OFCs).

The FSB's charter is more prescriptive. It mandates that each member country: (1) be subjected to IMF/WB FSAPs every five years with published assessments used as a basis for ROSCs; (2) implement international standards; and (3) undergo peer reviews within the FSB as well assessments performed by the IMF. Moreover, the process of "name and shame" may be extended beyond the OFCs to other non-member countries (Helleiner 2010).

This mandatory approach would constitute a substantial improvement were it to significantly increase the number of systemically important countries that comply with international standards and IMF/World Bank financial-sector surveillance. However, as of September 2008, all but four of the regular members of the G-20 had already participated in the financial-sector surveillance process. The exceptions were Argentina, China, Indonesia, and the United States (Truman 2010c). Notably, the United States has just completed its FSAP/ROSC process with the IMF/WB and those for China and Indonesia are also underway. ${ }^{34}$

The more difficult and pressing postcrisis challenge faced by the FSB is to improve further the existing standards and practices that shape financial regulation and accounting, supervisory frameworks, and day-to-day supervisory practices. As we discussed in earlier sections, this challenge is especially pressing in the major financial centres where the crisis revealed key weaknesses in the supervisory and regulatory architectures. The mandating of FSAPs every five years and the peer-review process within the FSB for members may help in this regard while at the same time creating possible conflicts with the work of the IMF and World Bank. But the onus is on the major financial centres, working through and with the FSB, to develop and implement more effective supervisory and regulatory frameworks, standards, codes, and best practices.

The FSF's charter on its face was at best ambiguous about the relationship between the FSF and the international SSBs. The Tietmeyer (1999, page 6) report assigned to the FSF the task of "creating procedures for coordinating the work of national and international regulatory groupings, and for the exchange and pooling of information among them." This formulation raised the question whether the FSF was a "rule maker" or "rule taker." As part of monitoring and coordinating, there may have been a two-way process. But the lack of a clear FSF oversight was seen by some as a shortcoming because one of the reasons for creating the FSF was to improve standards and compliance with them.

\footnotetext{
${ }^{34}$ See the US FSAP documents on the IMF website (www.imf.org).
} 
In this regard, the FSB takes three qualified steps forward for influencing SSBs' work and decisions. In particular, FSB members have agreed: ${ }^{35}$

- SSBs will report to the FSB on their work-with the objective of strengthening support for strong standard setting by providing a broader accountability framework — but without prejudice to the SSBs' independence and existing reporting arrangements.

- The FSB will undertake joint strategic reviews of the policy development work of the SSBs to ensure their work is timely and coordinated, focuses on priorities, and addresses gaps.

- The FSB will promote and help coordinate the alignment of the activities of SSBs to address any overlaps or gaps and clarify demarcations in light of changes in national and regional regulatory structures relating to prudential and systemic risk, market integrity and investor and consumer protection, infrastructure, as well as accounting and auditing.

While these principles defining the FSB's relationship with the SSBs may be an improvement over the FSF, it is unclear whether the FSB has the clout to influence the agenda and content of the work of the SSBs. One can see the tension in the language used in the FSB's charter. Moreover, arguably the most important of the SSBs is the BCBS. The BCBS now formally reports to the Group of Governors and Heads of Supervision as its oversight body. That group, now chaired by ECB President Jean-Claude Trichet, consists of the G-20 central bank governors and the supervisors from the G-20 countries. Until 2009, the Group of Governors and Heads of Supervision was an informal body. It was created to resolve the ambiguous situation that came to exist between the G-10 central bank governors, which established the BCBS in 1974 and to which the BCBS previously "reported," and the evolving membership of the committee that increasingly included banking supervisors that were not part of their national central banks because central bank involvement in banking supervision was scaled back or eliminated.

Since 2009, the IMF has had observer status on the BCBS and it participates with other international institutions on the Basel Consultative Group involving larger emerging market countries, such as Chile, Malaysia, and Thailand, which are not represented on the BCBS, which does now include all the G-20 countries.

Our inference is that, while there is scope for a two-way interaction during the process of standard development, by the time BCBS proposals reach the FSB, which also includes representation of 17 finance ministries and international institutions, the decision to support them is essentially a formality. In countries where policy development is well coordinated between finance ministries, central banks, and supervisors, this three-tier structure many not matter with respect to the substance of national positions, but the voices of the other international organisations in the final approval process are absent.

\section{Macroprudential Orientation}

As we argued in the previous section, an important failure of the precrisis framework for safeguarding global financial stability was that it was focused too heavily on microprudential regulation and supervision and not enough on assessing, monitoring, and resolving problems at the system-wide level. In our view, the macroprudential orientation of supervision and regulation should have two major focal points: (1) the impact of the aggregation of financial risks on the

\footnotetext{
${ }^{35}$ See the FSB's charter (Financial Stability Board 2009).
} 
system as a whole, including externalities and cross-correlations of risks (that is, a focus on systemic risk); and (2) the impacts on the financial system as a whole of macroeconomic policies-monetary, fiscal, and financial.

The first focal point has a regulatory dimension, as well as an ongoing supervisory dimension. The regulatory dimension involves restructuring the regulatory system to improve the ex ante alignment of incentives and to minimise ex post any unwanted consequences such as moral hazard. ${ }^{36}$ The supervisory dimension involves the aggregation and calibration of the importance of risks across financial institutions or the financial sector as a whole. The second focal point requires assessing whether macroeconomic policies are encouraging or contributing to financial imbalances and systemic risks.

We would submit that when the FSF was established in 1999, and in the wake of the crisis of 2007-10, sufficient attention was not paid and is still not being paid, to this second focal point. The boldest evidence of this bias is, first, the lack of consensus on how monetary policy should deal with asset-price bubbles, and more broadly on the role of monetary (and more generally macroeconomic) policies in contributing to the conditions that caused and facilitated the recent crisis. Second is the widespread, but not universal, rejection of the view that aggregate quantities are relevant for assessments of systemic risk and financial stability, for example, the growth of aggregate credit (private and public) and off-balance sheet leverage.

Whatever one's view about the role and definition of macroprudential concerns, going into the recent crisis the GFA, to a considerable degree, was intellectually and operationally oriented toward ensuring the safety and soundness of individual institutions and toward thinking that this would be sufficient to safeguard systemic financial stability.

This ineffective orientation need not have been so. One reason why the FSF was originally established was to provide a forum for national central bankers, supervisory and regulatory authorities, officials from SSBs, and finance ministry officials to discuss these matters at arm's length -including with the international institutions. ${ }^{37}$ As originally envisaged by Hans Tietmeyer (1999, page 6) in his report to the G-7 finance ministers and central bank governors for the establishment of the FSF, one of the four early action areas for the FSF was "improving arrangements for surveillance of global vulnerabilities including the pooling of information available to the IFIs [important financial institutions] and the international regulatory groupings, the development and assessment of macro-early-warning indicators, and the creation of procedures to ensure that information reaches the relevant parties. ${ }^{\text {38 }}$ The FSF did convene a vulnerabilities group — composed of key representatives from a small number of members with expertise in market surveillance and systemic risk assessment-in order to identify sources of risks and vulnerabilities so that the FSF could recommend remedial actions when and where necessary.

One possible reason why the FSF itself may have limited its attention to the macroeconomic policy aspects of macroprudential supervision is that central banks with some reasonable justifications tend to be reluctant to discuss or analyze their (monetary and

\footnotetext{
${ }^{36}$ See the exposition in Hanson, Kashyap, and Stein (2010) in which the authors define the macroprudential approach to capital regulation as an "effort to control the social costs associated with excessive balance-sheet shrinkage on the part of multiple financial institutions hit with a common shock."

${ }^{37}$ Central bankers outnumber finance ministry officials on the FSB 27 to 17.

${ }^{38}$ The other three action areas were: (1) the coordination of the work of national and international regulatory groups;

(2) assessing the need for the regulation of nonregulated entities (hedge funds and those operating out of offshore financial centres); and (3) encouraging the development and implementation of international best practices and standards.
} 
macroprudential) policies in a forum that includes outsiders, including other central banks as well as supervisory authorities, finance ministries, and other organisations. Out of the 36 seats at the FSF table initially, almost a third (11) were occupied by representatives of central banks or central bank institutions, such as the BIS, or central bank committees. The original intent of the FSF was and of the FSB is to expand these open discussions precisely to fill in gaps of information and analyses between central banks, supervisory authorities, and finance ministries. Thus, a continuation of this practice will most likely be self-defeating once again.

The FSF did address in its vulnerability discussions some of the aggregated aspects of macrofinancial imbalances and their implications for macroprudential policies, but with insufficient value added to head off the crisis. Much of the FSF's attention was concentrated on financial institutions for which there was little available data and information (such as highly leveraged institutions and other types of nonbank financial institutions), international standards and codes, and of course the crisis of the day, such as Argentina or Turkey.

The charter of the FSB tries to redress this balance by more explicitly acknowledging a role for the FSB in macroprudential assessments in concert with the IMF. Three of the FSB's assigned tasks can be interpreted as macroprudential in nature: assessment of vulnerabilities affecting the global financial system, monitoring and advising on market developments, and collaborating with the IMF to conduct early warning exercises (FSB 2009). ${ }^{39}$ It is unclear at this point whether this new FSB focus on macroprudential issues is oriented toward the aggregation aspects and away from the macroeconomic policy aspects as described above. We suspect that it is. We note that the FSB as initially reconstituted includes among its 69 initial members 27 (more than one-third) from central banks or their institutions.

\section{Accountability and Transparency}

As a coordination mechanism, the FSB in principle should be able, at least, to consider how to internalise many of the externalities that exist in global finance. One would hope that they would also be successful in formulating coordinated policy solutions that would actually internalise many of these externalities, for example to manage systemic risks in the global over-the-counter derivatives markets. Internalisation of finance-related externalities can occur through information sharing, through the development of international standards, codes, and best practices, and through policy formulation and implementation. This is an essential process for promoting collective action with the objective of improving the ability to safeguard global financial stability.

Because the transparency of the FSB's work is largely confined to the publication of its consensus reports and findings, much of what is learned in reaching a consensus cannot find its way into the public domain. The consultation documents of the SSBs do provide a bit more transparency. However, for the severe critics in the NGO and academic community, the SSBs are the regulators to which the regulated have privileged access with the result that accountability and transparency of their processes are inherently suspect and the FSB layer only adds the central bankers and representatives of finance ministries, which are no better in this regard.

There are three potential problems with this lack of transparency. The first two involve non-member countries. First, while non-member countries have direct access to all FSB website

\footnotetext{
${ }^{39}$ The other five identified tasks are: promotion of information exchange, promotion of regulatory best practices, reviews of the work of the international standard-setting bodies, guidelines for supervisory colleges, and contingency planning with respect to systemically important firms. (See box 2.)
} 
published reports and even some indirect access through the bodies that are FSB members, non members, as discussed above, by-and-large do not see this as sufficient involvement in the formulation of the standards, codes, and best practices to which they are expected to adhere. This is one reason why the FSB was expanded to include the G-20 countries, but this may not be sufficient.

A second potential problem involving non members is that non members only get to see the work of the FSB that the SSBs decide to publicise. This is likely to continue to be confined to consensus documents. However, the process of reaching a consensus is itself an important part of the information flow; it is a learning process that takes place within committees and between national authorities with varying degrees of experience and through information and analyses sharing. Non-member countries do not have the opportunity to share fully in this learning process of the dialogue, debate, and consensus-building process of FSB deliberations, meetings, and report researching and writing.

The third potential problem is with respect to the public at large. The issue is whether the FSB - because it is further removed from the political processes of the member governmentsaccentuates perceived structural problems at the national level. The insiders are the gatekeepers to influencing the regulatory process and the capacity of the guardians of the public interest in such matters is severely attenuated. The charter of the FSB does call upon it to "consult widely" not only among its members but also with other stakeholders identified as the private sector and non-member authorities. Some observers are concerned about too much consultation with the former and too little with the latter. The ultimate governance over the FSB and its deliberations is exercised somewhat removed from governance at the national level by electorates, publicinterest groupings - including affected industries — and more generally through public perceptions and opinion. It should be acknowledged that some regard this independence as a plus, but in individual societies striking the right balance between independence and accountability is not easy, and across societies it is even more challenging. The most limited standard tends to prevail.

\section{Implications for the Global Financial Architecture}

This section examines the implications of our preceding analysis of the institutions of the global financial architecture for the principal issues facing the global financial system. The IMF and FSB are different organisations with separate, but overlapping, mandates. Nevertheless, in the aftermath of the crisis, they have been asked to enhance their cooperation in key GFA reform areas. Thus, we first compare and contrast these two GFA-central institutions, and second we consider the extent to which they are positioned to address the six major issues coming out of the crisis of 2007-10 that we earlier identified.

\section{The Central Global Institutions}

The IMF and the FSB are the principal institutions of governance of the global financial architecture. The immediately preceding section reviewed the strengths and weaknesses of each institution individually, but it is useful to summarise that review via comparison.

By virtue of universal membership and representation the IMF is seen as having greater legitimacy (as we have defined that term) than the FSB. But the IMF still falls short of the ideal in the view of many observers. Although universal, the IMF currently faces its own challenges to 
adjust its representation with respect to voting shares and voices from chairs. European countries have a disproportionate share of the votes and voices at the IMF. They also have a disproportionate share of the voices at the FSB. ${ }^{40}$ One difference between the two organisations is that the IMF is dominated by the views of governments as articulated by more politically responsible finance ministries. In the FSB the views of independent central bankers and supervisors have substantially greater influence.

Turning to tools and instruments, the IMF has a limited set of policy tools in its lending, surveillance, research, and technical assistance activities. The FSB is principally a coordinating body with few tools aside from its own nascent peer-review processes, which potentially are in conflict with those of the IMF itself.

On compliance and leverage, the FSB is a voluntary organisation and compliance with its decisions and recommendations depends on the independent actions of its member countries and non member countries. As noted, the FSB is experimenting with a peer-review process applied to its own members, and has been mandated by the G-20 to conduct a review of the supervisory policies of non members. This could lead to some degree of naming and shaming and subsequent response by both members and non members. Its predecessor, the FSF, did some of this; however, the subsequent reliance on IMF assessments of offshore financial centres because of that institution's greater resources and legitimacy failed to generate meaningfully differentiated assessments. The IMF, for its part, has some — but is not overly well endowed with-leverage, in particular over its largest members. The principal instruments are its lending programmes, its surveillance activities, which may be more credible than those of the FSB, and its large professional staff. The IMF, as well as the World Bank, has an internal governance structure that provides scope for the expression of independent staff views.

The IMF, along with the World Bank for developing countries, disseminates and evaluates compliance with international standards, codes, and best practices in each of its member countries. In principle, it is positioned in the future to assume a greater (still informal) financial regulatory role in both its country and multilateral surveillance work and in joint IMF/World Bank/FSB efforts in financial-sector surveillance not only for the FSB member countries but for the universal membership of the IMF. At present, the IMF has a critical shortage of the relevant staff expertise to conduct this work effectively on its own and must draw on independent experts and at times member countries' government experts.

The macroprudential orientation of the IMF is greater than that of the FSB by dint of its broader remit and more extensive experience on macroeconomic issues. The IMF and the FSB have been called upon by the G-20 to enhance their cooperation in conducting early warning exercises. This is a ramping up of the vulnerabilities exercises that the FSF was asked to coordinate when it was first established. The crisis revealed that neither the IMF nor the FSF individually or collectively were able to provide much value-added via their vulnerabilities, early warning, and surveillance activities. We think this judgment of low value-added is justified by the lack of success in providing the kind of consistent and credible risk and vulnerability assessments that would move policymakers to action to prevent or at least lessen the impact of potential systemic events and ultimately the global financial crisis.

Going forward, a key challenge is whether the new early-warning systems will be more effective. The G-20 countries - as members of the IMF — already are subject to the IMF's annual bilateral surveillance and its global financial system surveillance conducted twice annually and published in its Global Financial Stability Report. In addition, the World Economic Outlook of

\footnotetext{
${ }^{40}$ Voices may be more important in the FSB given that it reaches decisions entirely via consensus.
} 
the Fund also often delves into the risks to the global economy emanating from global financial imbalances and market pressures. The G-20 countries influence the work programme of the IMF through their role in the governance of the institution.

What more can the FSB add to the work of the IMF management, staff, and executive board? One answer might be that the FSB has more of a comparative advantage in the aggregation dimension of macroprudential supervision, and the IMF might have a comparative advantage on the macroeconomic policy dimension. However, that division of labour is complicated by the fact that central banks essentially are not and do not want to be engaged with the Fund, and are more engaged with the FSB even though they may be reluctant in any institutional context to consider the global impact of their monetary policies on financial stability. In the end, it is not appropriate to view the exercise of the traditional tools of monetary policy (interest rates) as separate from the use of other so-called macroprudential tools because monetary policy affects the financial system and financial system supervision-regulation in particular - and adjustments to that supervision and regulation to achieve financial stability, affect the performance of the macroeconomy. ${ }^{41}$ As wisely observed by Fischer (2009), coordination is essential.

Finally, with respect to accountability and transparency, neither the IMF nor the FSB is exempt from criticism. Nevertheless, the edge goes to the IMF in part because of the breadth of its membership and the more avenues it has to open up to the general public. The FSB is a more closed club of supervisors, central bankers, and selected finance ministry officials. ${ }^{42}$

\section{The IMF, the FSB, and the Principal GFS Issues}

In the wake of the 2007-10 crisis, the substance and modalities of IMF collaboration with the FSB and vice versa are not fully established. For the general public the operative framework is contained in a joint letter from IMF Managing Director Dominique Strauss-Kahn and FSB Chairman Mario Draghi dated November 13, 2008 and addressed to the G-20 finance ministers and central bank governors (Strauss-Kahn and Draghi 2008). Note that the letter predates the transformation of the FSF into the FSB and specifies the respective roles of the IMF and the FSF:

1. Surveillance of the global financial system is the responsibility of the IMF.

2. Elaboration of international financial sector supervisory and regulatory policies and standards, and coordination across the various standard-setting bodies, is the principal task of the FSF. The IMF participates in this work and provides relevant inputs as a member of the FSF.

3. Implementation of policies in the financial sector is the responsibility of national authorities, who are accountable to national legislatures and governments. The IMF assesses authorities' implementation of such policies through FSAPs, ROSCs and Article IVs.

4. The IMF and the FSF will cooperate in conducting early warning exercises. The IMF assesses macrofinancial risks and systemic vulnerabilities. The FSF assesses financial system vulnerabilities, drawing on the analyses of its member bodies, including the

\footnotetext{
${ }^{41}$ On the effects of central bank monetary policy on the stability of the financial system see Giavazzi and Giovannini (2010).

${ }^{42}$ An examination of the websites of each organization provides the basis for our evaluation of their relative transparency.
} 
IMF. Where appropriate, the IMF and FSF may provide joint risk assessments and mitigation reports.

The letter concludes "Our shared goal is to strengthen the international financial system. To that end, the IMF and the FSF stand ready to support the work of the G-20."

A few points are notable about this document. First, the letter is oriented toward the work of the G-20 finance ministers and central bank governors in the precrisis context rather than toward the G-20 leaders to which the FSB is formally responsible, in the postcrisis environment of a substantially transformed landscape of regulation. Second, the letter acknowledges that, as previously, the IMF has a role to play with respect to the setting of standards, for example drawing on the analyses and experience of IMF staff and drawing up certain standards such as with respect to data reporting. Third, although the IMF was assigned responsibility with the World Bank in the late 1990s for assessment of the implementation by national authorities of regulatory policies and standards, subsequently the FSB has assumed a portion of that role vis-àvis the G-20 countries themselves as well as non members. A relevant question is: Although the FSB secretariat has a capable, professional staff, does it have the kind of human capital—both in expertise and scale - to add value to the Fund's and, in the case of FSAPS and ROSCs, also the World Bank's resources and efforts in these areas? Notably, neither the IMF nor the Bank has sufficient in-house expertise and resources, and there remains the challenge of ensuring the armslength independence of the resources that they hire temporarily from member countries. Some of this risk that the examined are also the examiners can be mitigated through the careful selection and allocation of "borrowed" resources, but the risk remains. This is less true of the Fund and Bank reviews of policies. In his criticism of the FSB-IMF relationship on this point, Fischer (2009) observes that the collegial nature of the FSB may limit a frank exchange of views and peer reviews may take the form of nonaggression pacts. In the IMF institutional context, a more independent staff and management increases the probability that sensitive issues at least will be raised.

How might this IMF-FSB framework apply to the six areas we earlier identified as particularly relevant for considering reforms of the global financial architecture?

\section{Regulatory Requirements for Capital, Liquidity, and Leverage and the Potential Benefits/Costs} of "Systemic-Risk" Taxes

The FSB and the SSBs would be expected to take the lead in the area of capital liquidity and leverage requirements, and they have largely done so. But the reality is somewhat more complex given the existing architecture for consensus building.

The current structure has the FSB reporting through the G-20 finance ministers and central bank governors to the G-20 leaders on capital, liquidity, and leverage for banks at their upcoming summit in Seoul, South Korea. Our understanding is that there is a continuous flow between the BCBS and the FSB on banking regulations and standards. ${ }^{43}$ Finance ministries that have a role in financial regulation and policies also exert direct influence over decisions. As one might expect, ministries tend to reflect the political pressures on reform efforts against the background of still-recovering financial institutions and systems. These pressures tend to call for a delay in implementation, if not the watering down, of capital, liquidity, and leverage requirements. G-20 leaders have also been involved, but as the Toronto summit revealed there

\footnotetext{
${ }^{43}$ The IMF is also involved because it has had "observer" status in the BCBS since mid-2009.
} 
are contrasting views on both capital and liquidity requirements and so a lack of consensus exists at the head-of-state level. Some argue that greater independence from political influences produces better regulations; others would argue that the regulations will be watered down via the influence of banks on finance ministries and regulators. ${ }^{44}$ Moreover, this reality may not sit well with the non-G-20 countries that presumably will be expected to apply these new banking standards to their internationally active institutions. Once endorsed by the G-20 leaders, the voluntary nature of such standards is more difficult to maintain. They will be incorporated directly and indirectly into IMF/World Bank reviews of all countries without the consent of most of them. The FSB in effect uses the IMF for leverage.

The G-20 leaders requested the advice of the IMF on the related issue of the costs and benefits of "systemic-risk" taxes. As noted earlier, the G-20 leaders appear to have rejected the uniform application of the IMF's advice from the management and staff (IMF 2010a), which proposed two taxes: (1) a financial stability contribution to cover the fiscal costs of any future crises; and (2) a financial activities tax on the profits and remuneration of financial institutions, which would flow to the general revenues to cover the wider costs of such crises and limit distortions that favor excessive size and risk taking by financial institutions. This example illustrates that the FSB is not solely responsible for proposals affecting the financial system and that the IMF has relevant expertise as well. ${ }^{45}$

Another question is the role that the FSB play in this process as a coordinating body. Member countries are undertaking reform efforts and expending political capital at home while implementing national policies aimed at national objectives. They may not align national efforts with agreements and understandings reached in the FSB. Europeans have criticised the US Dodd-Frank legislation in this regard and the United States has been critical of some European thinking and initiatives. This tends to undermine the FSB's effectiveness.

\section{Perimeters or Boundaries of Financial Regulation, Supervision, and Infrastructures}

It would be natural to think that the countries that are members of the FSB should take the lead in this area, and therefore the FSB itself. However, even more so than with the area previously discussed, this topic involves primarily only a few key jurisdictions. Even the FSB may be too large a group to reach agreement, for example, on the appropriate degree of regulation and surveillance of hedge funds. On the other hand, when it comes to infrastructures, the interests of a very broad group of countries are potentially involved, and the FSB may be too small a group to command full acceptance and compliance. This suggests a potentially important role for the IMF.

\section{Regulation and Surveillance of Global Money and Financial Markets}

When it comes to the regulation and surveillance of global money and financial markets, in particular OTC derivatives markets, the arguments advanced with respect to the regulatory and supervisory perimeter hold with even greater force. While it is natural to think that

\footnotetext{
${ }^{44}$ See Murphy and Jenkins' (2010) take on what has already been agreed by the BCBS and endorsed by its oversight body, "the principles outlined . . . contained far-reaching concessions."

${ }^{45}$ In April 2009, the G-20 leaders requested a joint IMF-FSB-BCBS report to the G-20 ministers and governors on the identification of SIFIs (FSB 2010).
} 
representatives from the major markets serving on the FSB should take the lead in this area, they also have their own axes to grind and turf to defend. It is not clear that their interests coincide with those of all participants in the global financial system. Thus, there is a role for the IMF in representing those less parochial and global interests as well as to provide a perspective from outside a closed circle to help to align incentives and help to internalise externalities.

\section{Systemically Important Financial Institutions or the TBTF Problem}

This area is one that involves the interests of the global financial system to a greater degree even than the two previous areas. Although it is natural that agreements would first be reached in the context of the FSB and the SSBs about how to treat SIFIs in life, near death, or in death, the consequences of countries' mistreatment or their clumsy treatment, as witnessed in the case of the Lehman and Fortis bankruptcies can affect many jurisdictions and creditors. In particular, if the global financial system is not to degenerate into one in which most financial institutions are heavily ring-fenced, as favored by many, or in which the authorities try, and more likely fail, to ring-fence them, global standards are needed. ${ }^{46}$

\section{Crisis Management, Rescue, and Resolution}

The IMF is the preeminent international organisation for country crisis management and country economic and financial rescues. That status has been enhanced in the crisis of 2007-10 by the fact that European countries that many thought were not or should not be in need of such rescue operations ended up needing the Fund's not-so-tender ministrations.

On the other hand, crisis management blends into crisis prevention both in anticipating crises and in learning lessons from them. It follows that the IMF alone cannot be held responsible. In particular, where frameworks need to be put in place to facilitate the rescue of institutions or their resolution, the IMF can prod the individual national authorities, but those authorities must collaborate in advance to set up the appropriate procedures. A forum such as the FSB is broadly appropriate to help to establish such understandings.

\section{Effective Management of Volatile Capital Flows}

As with crisis management, the IMF is the natural locus of decision making with respect to establishing a framework for the more effective management of volatile capital flows. If as a consequence of lessons learned from the crisis of 2007-10 the IMF is to become more of an international lender of last resort than it has been in the past, as some have proposed in the form of global financial safety net, should the Fund have a more enhanced role in regulation? One of the arguments for such a role is that it would help to deal with the moral hazard issues associated with lender-of-last-resort activities by linking the availability of financing more directly to prior supervision or surveillance. ${ }^{47}$

Alternatively, is it sufficient for the Fund to play a role in other international bodies, such as the FSB, that have the mandate to reach agreements on the principles and standards to be

\footnotetext{
${ }^{46}$ The question is whether the FSB acting alone can deliver those standards or whether a more representative group should be involved. It should be noted that the IMF staff has opined on this topic (IMF 2010c and Kodres and Narian 2010). Rottier and Véron (2010) emphasize the growing risk of fragmentation in the global financial system. ${ }^{47}$ For more on this line of argumentation see Truman (2010b).
} 
applied in supervision and regulation? Similarly, is it sufficient for the IMF to share responsibility with respect to early warning systems? Whether responsibility for early warning systems is shared or not, the relevant concern is not with who issues the warnings but whether the authorities take action in response to those warnings (Fischer 2009 and Schinasi 2009b).

From another perspective, how can the FSB best add value to work in this area without duplicating the efforts of the IMF and, perhaps, even affect perceptions of the IMF's legitimacy? For example, with the new enhanced role of the FSB (as a creature of the more political G-20) in rule making and the associated closer scrutiny of the IMF's work in this area, non-G-20 members of the IMF may come to question the IMF's role and importantly its capacity to serve the interests of its non-G-20 as well as G-20 members.

\section{Conclusions and Recommendations}

Our broad conclusion is that the structural financial weaknesses revealed by the global crisis require further reforms of the global financial architecture if future crises are to be managed and resolved more cost effectively, both in terms of preserving the efficiency gains of global modern finance and in terms of taxpayer monies. First and foremost, reforms are required at national levels. However, to maximise the probability that these reforms contribute to greater stability of the global financial system and are implemented consistently, the financial-stability roles of the relevant international institutions, the IMF and FSB in particular, should be enhanced individually and collectively. More specifically, the IMF and the FSB must cooperate and collaborate as closely as possible on the reform and operation of the global financial system in order to achieve their mandated objectives that overlap in many areas.

Our assessment is that the global financial architecture will not soon include a global financial regulator that is empowered to replace or even substantially influence sovereign supervision and regulatory decisions. In particular, as currently constituted and situated, the FSB is not positioned to become the fourth pillar of global economic governance as was suggested by US Treasury Secretary Geithner. It has been called upon to cooperate with the IMF and vice versa, and the collaboration should be mutually reinforcing, drawing on the respective strengths of the two institutions. By cooperating with the IMF, the FSB may enhance its accountability and transparency to stakeholders in the global financial system. By cooperating with the FSB, the IMF may gain greater trust from central bankers and supervisory and regulatory authorities and in the process enhance its leverage with these policymaking organisations.

Is there a case to be made for greater separation between the IMF and the FSB because they have different, if overlapping, mandates? Is there a concern that forcing more collaboration between the two institutions will reduce accountability? The answer is yes to both questions. However, our view is that the crisis has increased the pressure on both institutions to add more value in the financial-stability sphere both individually and collectively, as mandated by the G20. Moreover, the business-as-usual model with its associated jealousies and turf battles will not meet the needs of the global financial system going forward.

The IMF and the FSB are different institutions, but their financial sector-stability operations and activities should be more closely aligned. The overall objective should be to tie the IMF and the FSB closer together rather than to allow them to compete, to remain distant, and to engage in turf wars.

Given the GFS reform challenges, the IMF must focus on macroeconomic and macrofinancial stability, the linkages between them, and the implications of macroeconomic 
policies for the stability of the global financial system. For its part, the FSB must focus its efforts on sponsoring the adoption of new international supervisory and regulatory standards that improve the ability to assess, monitor, and hopefully maintain systemic financial stability in addition to the safety and soundness of financial institutions. As noted earlier, this challenge is especially pressing in the major financial centres where the crisis revealed key weaknesses in the supervisory and regulatory architectures. Accordingly, the major onus is on the major financial centres, working through and with the FSB, to develop and implement more effective supervisory and regulatory frameworks, standards, codes, and best practices. In addition, it is an important responsibility of the FSB - even if it is not explicitly mandated — to facilitate the coordination of reforms among the country membership to the benefit of global stability in areas where unilateral actions are unlikely to be effective in safeguarding global stability.

In this regard, international standards and best practices that are likely to have the highest payoff are in the following areas:

- capital, liquidity, and leverage standards of financial institutions;

- resolution of complex cross-border financial institutions;

- rescues of such financial institutions short of their resolution; and

- determination of whether a financial institution, market, or instrument is systemically important.

However, these focal points clearly interact and overlap. In both institutions, the need is to try to affect national policies and priorities. In general, reform efforts should be aimed at improving the ability to foresee and prevent future crises and to resolve the next one when it occurs.

To mitigate the dominance of national priorities in the FSB's work, we recommend that the international organisations that are members of the FSB - the IMF in particular — should be empowered and emboldened to facilitate the dialogue between member countries so that national reform efforts and policies focus on global externalities and priorities. This was the original intent of the IMF's multilateral consultation exercise on global imbalances in 2007-10 involving China and the United States along with the euro area, Japan, and Saudi Arabia. Perhaps the IMF can play this role in the financial-stability sphere within the context of the FSB's discussions. ${ }^{48}$

The challenge of managing volatile capital flows provides the scope and opportunity for a bargain between historically dominant countries and the emerging-market countries for the greater involvement of the emerging countries, including the macroeconomic, regulatory, and financing aspects of this challenge. As is now better understood, both micro- and macroprudential policies can help to manage the risks associated with volatile capital flows and in so doing allow countries to rely less on costly self-insurance in the form of high levels of international reserves. This topic should be on the agenda of the FSB-initially it was on the agenda of the FSF-as well as that of the IMF.

In this regard, both the IMF and FSB need to address institutional representation issues per se. For example, prior to the crisis and the recent reform efforts, Europe (including Switzerland) and the United States played dominant roles relative to all other country groups. With the emergence of volatile capital flows and new major players (among them several

\footnotetext{
${ }^{48}$ This kind of arrangement need not apply in all cases; for example, the key players on some issues may include only a small set of countries, and it is not clear that the presence or active engagement of a mediator or facilitator would advance the process. Recall that the Basel I capital standard was built on a bilateral agreement between the US and UK authorities after the Basel Committee on Banking Supervision demonstrated its inability to come to grips with the issue.
} 
emerging-market countries and smaller financial centres—such as Hong Kong, Special Administrative Region [SAR] and Singapore), there is a need to rebalance the influence structure toward more inclusiveness and representation on relevant issues and policy challenges without compromising standards.

The need for such institutional governance reform is overwhelming in the case of the IMF, which, as an older institution, has ossified for a longer period. In the case of the FSB, its governance structure should in due course be streamlined, for example, by dramatically consolidating European representation, building on a consolidation of European representation on the IMF executive board and in other governance bodies such as the IMFC. That desirable step within the FSB also will require greater consolidation of the European financial regulatory and supervisory structure than is likely to result immediately from the recent crisisnotwithstanding the European progress that has already been achieved.

It may ultimately be desirable to move within the FSB to a constituency system, but that would have to wait for the adoption of such a system within the G-20 leaders and finance ministers and central bank governors groups. We do not think that this is the most urgent issue facing the G-20 groups today.

Short of expanding its membership, a key issue for the FSB is to engage effectively the large number of non-member countries and persuade them to adopt the standards the SSBs develop and the FSB proselytises. To open its doors more, deliberations of the FSB should be routinely publicised, including on the issues where it cannot reach a consensus and why. As we understand is intended, the FSB should resume regional meetings with regulators from nonmember countries and routinely provide them with information on the agenda for FSB meetings, papers, and outcomes. This would improve the ability of non-member countries to learn and benefit from the work of the FSB that does not get published because it is in areas where consensus cannot be attained.

The IMF, similarly, is less open about deliberations of its executive board than it can and should be. The internal debates at the executive board level are obscured, for example, by incomplete concluding-remarks references to country positions of "a few," "some," or "many" directors and many documents are not released until decisions have been made, for example, on quota realignments.

The balance of roles for the authorities of their respective memberships within the IMF and FSB should be addressed. Within the IMF, the global crisis has had implications for the roles of central banks vis-à-vis finance ministries. The IMF, in particular, must engage more with central banks and vice versa because of the now more widely acknowledged close interlinkages and policy challenges in simultaneously achieving and safeguarding both macroeconomic and financial stability. As the global crisis demonstrated, a slavish defense of central bank independence in the narrow pursuit of (for example) price stability, or of macroeconomic stability, can become inconsistent analytically and institutionally with the need to rely on macroeconomic tools to restore or to pursue financial stability. Naturally, the extent of inconsistencies will depend on the specific mandate(s) of a particular central bank, but are most likely to become critical soon enough for central banks with mandates focused exclusively, or overridingly, on price stability. Contrary to its past practice, the IMF management and staff should exploit the FSB to engage with central bankers collectively on these issues because it has no other regular forum in which to do so.

To tie the FSB and IMF closer together in recognition of their overlapping missions and mandates, we recommend a formalisation of the current de facto practice of the FSB reporting to 
the IMF's International Monetary and Financial Committee (IMFC) in addition to the G-20 ministers and governors and G-20 leaders. ${ }^{49}$ This would help defuse concerns about FSB legitimacy. We also recommend that strong consideration should also be given to provide the IMF with the "authority" to call on the FSB, perhaps through the IMFC, to consider certain issues and to report back-just as the G-20, and implicitly the FSB, now call on the IMF to consider and deliver on certain issues.

To enable the IMF to provide more effective surveillance over national financial systems and the global system, the Fund needs more in-house expertise and resources in relevant areas. We also favor increasing the resources available to the FSB secretariat to fortify its own permanent professional staff. Short of this, resources should be added to the secretariat on the current seconded basis so that it has the capability to contribute to the FSB's efforts with its own analytical work in core areas. We think the risk of duplicating the IMF's staff work is worth taking. Consideration should also be given by both the IMF and the FSB to the active, continuous use of panels of independent experts to review the work of the institutions as it evolves in the period ahead. This would help to address the perceived problem of capture of regulatory and supervisory authorities and institutions.

A longer-term option is to consider placing the FSB secretariat under the auspices of the IMF. This would require a clear set of understandings, for example about how the G-20, IMF executive board, and G-20 FSB representatives interact and are governed. In addition, there would also need to be guidance and understandings on the extent to which the FSB could draw upon the Fund's human capital for FSB work beyond the Fund's own contributions to FSB work as an FSB member. ${ }^{50}$

The FSB should adopt the practice of dual chairs for its standing committees and working groups, including one chair from one of the advanced countries and one chair from other members. Care should be taken not to perpetuate such a system indefinitely because it cuts against broader globalisation trends in which all countries are treated the same, but for the next 5 to 10 years it would be desirable.

Within the institutions and country groups that make up the GFA, substantive policy challenges often condition international policymaking, coordination, and governance. For example, the European Union and United States both desire reforms in areas that require international or global consensus and agreement to be effective and to achieve a level playing field such as the cross-border supervision and resolution of systemically important financial institutions and the OTC derivatives markets. At the same time, because of financial globalisation, without greater global coordination facilitated by the IMF and FSB working together, it is unlikely the European Union and the United States will be able to achieve desired reforms in many areas.

The only way to achieve the potential benefits of collective action is to establish the conditions for closely coordinated policy development and implementation. This may require significantly more give and take among countries than is now extant as well as strengthened roles for both the IMF and the FSB within the global financial architecture. Such a reorientation would endeavor collectively and equitably to create, manage, and capture the benefits of global public goods for the global financial system. International and global collective action to

\footnotetext{
${ }^{49}$ We join de Larosière (2009, page 61) in this recommendation with respect to the FSB's predecessor the FSF.

${ }^{50}$ The IMF's new income model, relying less on charges on loans because of the availability of income from investments on the profits from gold sales, should lessen these concerns somewhat. The Fund will be better positioned to produce a wider array of public goods.
} 
safeguard financial stability has to flow from a shared interest in the objective of financial stability.

Table 1 IMF and FSB policy focus, tools, and governance.

\begin{tabular}{|c|c|c|}
\hline & International Monetary Fund & Financial Stability Board \\
\hline Policy focus & $\begin{array}{l}\text { Exchange-rate-system and } \\
\text { balance-of-payments equilibrium } \\
\text { - Member-country macroeconomic } \\
\text { and financial stability } \\
\text { - Global economic and financial } \\
\text { stability }\end{array}$ & $\begin{array}{l}\text { - International standards and best } \\
\text { practices for financial regulation } \\
\text { and supervision } \\
\text { - Global financial stability }\end{array}$ \\
\hline Tools & $\begin{array}{l}\text { - Financing facilities for balance- } \\
\text { of-payments needs } \\
\text { - Bilateral and multilateral } \\
\text { surveillance } \\
\text { - Technical assistance }\end{array}$ & $\begin{array}{l}\text { - Identification/assessment of } \\
\text { sources of global financial } \\
\text { vulnerabilities } \\
\text { - Facilitate development of } \\
\text { remedial policies to } \\
\text { safeguard/restore stability } \\
\text { - Facilitate coordination of } \\
\text { member-country financial-system } \\
\text { policies }\end{array}$ \\
\hline $\begin{array}{l}\text { Internal } \\
\text { governance } \\
\text { structures }\end{array}$ & $\begin{array}{l}\text { Board of Governors consisting of } \\
\text { one governor and alternate for } \\
\text { each of the } 187 \text { member } \\
\text { countries (usually the finance } \\
\text { minister or central bank } \\
\text { governor) } \\
\text { - Executive Board in continuous } \\
\text { session } \\
\text { - IMF Management and Staff } \\
\text { - International Monetary and } \\
\text { - Financial Committee } \\
\text { Development Committee }\end{array}$ & $\begin{array}{l}\text { Plenary, comprised of G-20 } \\
\text { central bank governors or } \\
\text { deputies, heads or deputies of } \\
\text { main supervisory/regulatory } \\
\text { agency, and deputy finance } \\
\text { ministers; and high-level } \\
\text { representatives of SSBs, central } \\
\text { bank committees, IMF, WB, BIS, } \\
\text { and OECD } \\
\text { - Steering Committee selected by } \\
\text { plenary } \\
\text { - Chairperson } \\
\text { - Secretariat drawn from members }\end{array}$ \\
\hline Accountability & - Member-country governments & - G-20 heads of state \\
\hline
\end{tabular}

Source: IMF and FSB Websites. 
Table 2 Pre-crisis framework for safeguarding global financial stability

\begin{tabular}{|c|c|c|c|c|}
\hline \multirow[b]{2}{*}{ Lines of defense } & \multicolumn{4}{|c|}{ Sources of cross-border systemic risk } \\
\hline & $\begin{array}{l}\text { Global financial } \\
\text { institutions }\end{array}$ & Global markets & $\begin{array}{l}\text { Unregulated financial } \\
\text { activities }\end{array}$ & $\begin{array}{c}\text { Economic and financial- } \\
\text { stability } \\
\text { policy mistakes }\end{array}$ \\
\hline $\begin{array}{l}\text { Market discipline and } \\
\text { transparency }\end{array}$ & Partial & Primarily & Exclusively & $\begin{array}{l}\text { Committee structures; } \\
\text { peer pressure; lack of } \\
\text { clarity and transparency }\end{array}$ \\
\hline Financial regulation & $\begin{array}{l}\text { National orientation with } \\
\text { international cooperation } \\
\text { on capital requirements }\end{array}$ & No formal regulation & No regulation & $\begin{array}{l}\text { No explicit framework } \\
\text { and ineffective } \\
\text { coordination and } \\
\text { cooperation }\end{array}$ \\
\hline $\begin{array}{l}\text { Microprudential } \\
\text { supervision }\end{array}$ & $\begin{array}{l}\text { National orientation with } \\
\text { cooperation on best } \\
\text { practices via Basel } \\
\text { process }\end{array}$ & Not applicable & No supervision & $\begin{array}{l}\text { International cooperation } \\
\text { proved inadequate to } \\
\text { supervise systemically } \\
\text { important financial } \\
\text { institutions }\end{array}$ \\
\hline $\begin{array}{l}\text { Macroprudential } \\
\text { supervision }\end{array}$ & If systemically important & $\begin{array}{l}\text { National market } \\
\text { surveillance; IMF } \\
\text { multilateral surveillance; } \\
\text { FSF vulnerabilities } \\
\text { discussions }\end{array}$ & $\begin{array}{l}\text { Some via surveillance of } \\
\text { national markets and } \\
\text { financial institutions }\end{array}$ & $\begin{array}{l}\text { National authorities and } \\
\text { international cooperation } \\
\text { failed to adjust } \\
\text { macroeconomic and } \\
\text { supervisory policies in } \\
\text { advance of systemic } \\
\text { pressures }\end{array}$ \\
\hline $\begin{array}{l}\text { Crises management and } \\
\text { resolution }\end{array}$ & $\begin{array}{l}\text { National legislation and } \\
\text { orientation }\end{array}$ & $\begin{array}{l}\text { National orientation with } \\
\text { some central bank } \\
\text { cooperation and } \\
\text { coordination }\end{array}$ & No framework & $\begin{array}{l}\text { No framework and } \\
\text { ineffective cooperation } \\
\text { and coordination }\end{array}$ \\
\hline
\end{tabular}

Source: Adapted from Schinasi (2007 and 2009a). 
Table 3 Evolution of membership and representation in the FSF and FSB

\begin{tabular}{|c|c|c|}
\hline & \multicolumn{2}{|c|}{ Representation } \\
\hline Initial membership & FSF & FSB \\
\hline Canada & 3 & 3 \\
\hline France & 3 & 3 \\
\hline Germany & 3 & 3 \\
\hline Italy & 3 & 3 \\
\hline Japan & 3 & 3 \\
\hline United Kingdom & 3 & 3 \\
\hline United States & 3 & 3 \\
\hline IMF & 2 & 2 \\
\hline WB & 2 & 2 \\
\hline BIS & 1 & 1 \\
\hline OECD & 1 & 1 \\
\hline BCBS & 2 & 2 \\
\hline IOSCO & 2 & 2 \\
\hline IAIS & 2 & 2 \\
\hline GCFS & 1 & 1 \\
\hline CPSS & 1 & 1 \\
\hline ECB & 1 & 1 \\
\hline \multicolumn{3}{|l|}{ Added to FSF in 1999} \\
\hline Australia & 1 & 2 \\
\hline Hong Kong & 1 & 1 \\
\hline The Netherlands & 1 & 2 \\
\hline Singapore & 1 & 1 \\
\hline \multicolumn{3}{|l|}{ Added to FSF in 2002} \\
\hline IASB & 1 & 1 \\
\hline \multicolumn{3}{|l|}{ Added to FSF in 2007} \\
\hline Switzerland & 1 & 2 \\
\hline \multicolumn{3}{|l|}{ Added to FSB in 2009} \\
\hline Argentina & & 1 \\
\hline Brazil & & 3 \\
\hline China & & 3 \\
\hline India & & 3 \\
\hline Indonesia & & 1 \\
\hline Mexico & & 2 \\
\hline Russia & & 3 \\
\hline Saudi Arabia & & 1 \\
\hline South Africa & & 1 \\
\hline South Korea & & 2 \\
\hline Spain & & 2 \\
\hline Turkey & & 1 \\
\hline European Commission & & 1 \\
\hline
\end{tabular}

Source:FSF and FSB websites. 


\section{Box 1 A Brief history of the Financial Stability Board}

The FSB was established in April 2009 as the successor to the Financial Stability Forum (FSF).

The FSF was founded in 1999 by the G-7 Finance Ministers and Central Bank Governors following recommendations by Hans Tietmeyer, President of the Deutsche Bundesbank. G-7 Ministers and Governors had commissioned Dr. Tietmeyer to recommend new structures for enhancing cooperation among the various national and international supervisory bodies and international financial institutions so as to promote stability in the international financial system. He called for the creation of a Financial Stability Forum.

G-7 Ministers and Governors endorsed the creation of the FSF at a meeting in Bonn in February 1999. The FSF would bring together:

- national authorities responsible for financial stability in significant international financial centres, namely treasuries, central banks, and supervisory agencies;

- sector-specific international groupings of regulators and supervisors engaged in developing standards and codes of good practice; international financial institutions charged with surveillance of domestic and international financial systems and monitoring and fostering implementation of standards; and

- committees of central bank experts concerned with market infrastructure and functioning.

The FSF was first convened in April 1999 in Washington.

In November 2008, the leaders of the G-20 countries called for a larger membership of the FSF. A broad consensus emerged in the following months toward placing the FSF on stronger institutional ground with an expanded membership - to strengthen its effectiveness as a mechanism for national authorities, standard-setting bodies, and international financial institutions to address vulnerabilities and to develop and implement strong regulatory, supervisory, and other policies in the interest of financial stability.

As announced in the G-20 Leaders' Summit of April 2009, the expanded FSF was reestablished as the Financial Stability Board (FSB) with a broadened mandate to promote financial stability.

Source: http://www.financialstabilityboard.org/about/history.htm. 


\section{Box 2 Mandate of the Financial Stability Board}

The mandate of the FSB is to:

- assess vulnerabilities affecting the financial system and identify and oversee action needed to address them;

- promote coordination and information exchange among authorities responsible for financial stability;

- monitor and advise on market developments and their implications for regulatory policy;

- advise on and monitor best practice in meeting regulatory standards;

- undertake joint strategic reviews of the policy development work of the international standard-setting bodies to ensure their work is timely, coordinated, focused on priorities, and addressing gaps;

- set guidelines for and support the establishment of supervisory colleges;

- support contingency planning for cross-border crisis management, particularly with respect to systemically important firms; and

- collaborate with the IMF to conduct early warning exercises.

As obligations of membership, members of the FSB commit to pursue the maintenance of financial stability, maintain the openness and transparency of the financial sector, implement international financial standards (including the 12 key International Standards and Codes), and agree to undergo periodic peer reviews, using among other evidence IMF/World Bank public Financial Sector Assessment Programme reports.

The FSB, working through its members, seeks to give momentum to a broad-based multilateral agenda for strengthening financial systems and the stability of international financial markets. The necessary changes are enacted by the relevant national financial authorities.

The FSB plenary meets two times per year and has calls as needed. To broaden the circle of countries engaged in work to promote international financial stability, the FSB also holds regional outreach meetings with non-member financial authorities.

Source: http://www.financialstabilityboard.org/about/mandate.htm. 


\section{Box 3 Role of the FSB's chairman}

According to the FSB's charter, the FSB chair:

- is appointed by the plenary from members for a term of three years;

- shall have recognized expertise and standing in the international financial policy arena;

- convenes and chairs the meetings of the plenary and of the Steering Committee;

- oversees the secretariat;

- is the principal spokesperson for the FSB and represents the FSB externally;

- shall be informed of all significant matters that concern the FSB;

- more generally, shall make all decisions and act as necessary to achieve the objectives of the FSB in accordance with the directions given by the plenary; and

- in the discharge of the functions as the chair, shall owe the duty entirely to the FSB and to no other authorities or institutions.

Source: http://www.financialstabilityboard.org/publications/r_090925d.pdf. 


\section{Box 4 Role of the FSB secretariat}

As stated in Article 15 of the FSB's charter:

(1) The secretariat shall be directed by the secretary general.

(2) The secretary general shall be appointed by the plenary at the proposal of the chair.

(3) The secretary general shall be under the responsibility, and shall act in accordance with the instructions, of the chair. The chair is responsible for providing general direction to the secretary general, in accordance with any directions given by the plenary.

(4) In appointing the secretariat staff, the secretary general shall, subject to the importance of securing the highest standards of efficiency and of technical competence, pay due regard to the importance of a balanced composition in terms of geographic regions and institutional functions.

(5) The secretary general and the secretariat staff, in the discharge of their functions, shall owe their duty entirely to the FSB and to no other authorities or institutions.

(6) The main responsibilities of the secretariat shall be the following:

(a) to support the activities of the FSB, including its standing committees and working groups;

(b) to facilitate cooperation between members and between the FSB and other institutions;

(c) to ensure efficient communication to members and others;

(d) to manage the financial, material, and human resources allocated to the FSB (including the appointment of staff who may be seconded by members);

(e) to maintain the records, administer the website, and deal with the correspondence of the FSB; and

(f) to carry out all other functions that are assigned by the chair or the plenary.

(7) The secretariat shall be located in Basel at the BIS.

Source: http://www.financialstabilityboard.org/publications/r_090925d.pdf. 


\section{REFERENCES}

Ashcraft, Richard, ed. 1991. John Locke: Critical Assessments. London: Routledge.

Blanchard, Olivier, and Gian Maria Milesi-Ferretti. 2009. Global Imbalances: In Midstream? IMF Staff Position Note 09/29 (December). Available at www.imf.org (accessed on July 24, 2010).

Brunnermeier, Markus, Andrew Crockett, Charles A. Goodhart, Avinash Persaud, and Myun Song Shin. 2009. The Fundamental Principles of Financial Regulation. Geneva Reports on the World Economy 11.

Bryant, Ralph C. 2010. Governance Shares for the International Monetary Fund: Principles, Guidelines, Current Status. Washington: Brookings Institution. Available at www.brookings.edu (accessed on July 22, 2010).

Caprio, Gerard, Jr., Asli Demirgüç-Kunt, and Edward J. Kane. 2009. The 2007 Meltdown in Structured Securitization: Searching for Lessons not Scapegoats. Paolo Baffi Centre Research Paper Series No. 2009-49.

Carmassi, Jacopo, Daniel Gros, and Stefano Micossi. 2009. The Global Financial Crisis: Causes and Cures. Journal of Common Market Studies 47, no. 5: 977-996.

Committee on Capital Markets Regulation. 2009. The Global Financial Crisis: A Plan for Regulatory Reform (May).

Davies, Howard, and David Green. 2008. Global Financial Regulation: The Essential Guide. Cambridge, MA: Polity.

De Larosière, Jacques. 2009. Report of the High-Level Group on Financial Supervision in the EU (February 25). Available at http://ec.europa.eu (accessed on August 1, 2010).

Elson, Anthony. 2010. The Current Financial Crisis and Reform of the Global Financial Architecture. The International Spectator 45, no. 1 (March): 17-36.

ECB (European Central Bank). 2006. Special Feature A: Identifying Large and Complex Banking Groups for Financial Stability Assessment. Financial Stability Review (December). Frankfurt: European Central Bank.

ECB (European Central Bank). 2007. Box 10: Special Feature A: Identifying Large and Complex Banking Groups for Financial Stability Assessment-An Update. Financial Stability Review (December). Frankfurt: European Central Bank.

ECB (European Central Bank). 2008. Financial Stability Review (December). Frankfurt: European Central Bank.

European Commission. 2009. The Presidency Conclusions of the Council of the European Union (June 19). 
Federal Reserve Bank of Cleveland. 2009. What to do about Systemically Important Financial Institutions. Available at www.clevelandfed.org.

Fischer, Stanley. 2009. Preparing for Future Crises. Federal Reserve Bank of Kansas City Jackson Hole Conference Financial Stability and Macroeconomic Policy. Available at www.kansascityfed.org (accessed on July 25, 2010).

FSB (Financial Stability Board). 2008. Enhancing Market and Institutional Resilience. Available at www.financialstabilityboard.org.

FSB (Financial Stability Board). 2009. Financial Stability Board Charter. Available at www.financialstabilityboard.org (accessed on July 23, 2010).

FSB (Financial Stability Board). 2010. Reducing the moral hazard posed by systemically important financial institutions: Interim report to G-20 Leaders. Available at www.financialstabilityboard.org.

FSB (Financial Stability Board), IMF (International Monetary Fund), and BIS (Bank for International Settlements). 2009. Guidance to Assess the Systemic Importance of Financial Institutions, Markets and Instruments: Initial Considerations. Report to G-20 Finance Ministers and Governors by the staffs of the IMF and BIS, and the Secretariat of the Financial Stability Board (October). Available at www.financialstabilityboard.org.

G-10 (Group of Ten). 1992. Recent Developments in International Interbank Relations (the Promisel Report).

G-10 (Group of Ten). 2001. Report on Consolidation in the Financial Sector (Ferguson Report). Available at www.imf.org.

G-20 (Group of Twenty). 2009. Declaration on Strengthening the Financial System (April).

G-20 (Group of Twenty). 2010. The G-20 Toronto Summit Declaration (June 27). Available at www.g20.utoronto.ca (accessed on July 26, 2010).

G-30 (Group of Thirty). 2009. Financial Reform: A Framework for Financial Stability (January).

Garber, Peter. 2009. Comments on paper by Garry Schinasi, US and EU Reform Efforts in Improving the Management of Systemic Financial Risk, prepared for conference An Ocean Apart? Comparing Transatlantic Responses to the Financial Crisis (September). Rome, Italy.

Geithner, Timothy F. 2009. Press Briefing on the G-20 Meeting. Pittsburgh (September 24). Available at www.ustreas.gov (accessed on July 31, 2010).

Giavazzi, Francesco, and Alberto Giovannini. 2010. Central Banks and the Financial System. NBER Working Paper 16228 (July). Available at www.nber.org (accessed on July 25, 2010). Cambridge, MA: National Bureau of Economic Research.

Giovannini, Alberto. 2010. Financial System Reform from First Principles. Centre for Economic Policy Research, Policy Insight No. 45 (January). 
Gold, Joseph Gold. 1981. Legal and Institutional Aspects of the International Monetary Fund. Washington: International Monetary Fund.

Goldstein, Morris, and Nicolas Véron. 2010. “Too Big to Fail”the Transatlantic Debate. Peterson Institute for International Economics Working Paper 10-TBD (forthcoming).

Gorton, Gary B. 2008. The Panic of 2007. NBER Working Paper 14358 (September). Cambridge, MA: National Bureau of Economic Research.

Gorton, Gary. 2009. Slapped in the Face by the Invisible Hand: Banking and the Financial Panic of 2007. Paper presented at the Federal Reserve Bank of Atlanta's Financial Market Conference (May). Available at www.frbatlanta.org.

Griffith-Jones, Stephany, Eric Helleiner, and Ngaire Woods. 2010. The Financial Stability Board: An Effective Fourth Pillar of Global Economic Governance? Waterloo, Canada: Centre for International Governance Innovation. Available at www.cigionline.org (accessed on July 26, 2010).

Hacche, Graham. 2009. The IMF Staff's View of the World: The World Economic Outlook. In Successes of the International Monetary Fund: Untold Stories of Cooperation at Work, eds. Eduard Brau and Ian McDonald. London: Palgrave Macmillan.

Hanson, Samuel, Anil K. Kashyap, and Jeremy C. Stein. 2010. A Macroprudential Approach to Financial Regulation. Draft prepared for publication in the Journal of Economic Perspectives (July).

Helleiner, Eric. 2010. The Financial Stability Board and International Standards. The Centre for International Governance Innovation G-20 Papers, no. 1 (June).

Herrmann, Sabine, and Dubravko Mihaljek. 2010. The Determinants of Cross-Border Bank Flows to Emerging Markets: New Empirical Evidence on the Spread of Financial Crises. BIS Working Paper 315 (July). Available at www.bis.org (accessed on July 30, 2010).

IMF (International Monetary Fund). 2009. Lessons of the Financial Crisis for Future Regulation of Financial Institutions and Markets and for Liquidity Management. Available at www.imf.org.

IMF (International Monetary Fund). 2010a. A Fair and Substantial Contribution by the Financial Sector. Final report by the IMF staff to G-20 (June). Available at www.imf.org (accessed on August 1, 2010).

IMF (International Monetary Fund). 2010b. How Did Emerging Markets Cope in the Crisis? Paper prepared by the Strategy, Policy, and Review Department (June 15). Available at www.imf.org (accessed on July 26, 2010).

IMF (International Monetary Fund). 2010c. Resolution of Cross-Border Banks: A Proposed Framework for Enhanced Coordination. Paper prepared by the Legal and Monetary and Capital Markets Department (June 11). Available at www.imf.org (accessed on August 24, 2010). 
Issing Committee. 2009. New Financial Order (February).

Jenkins, Patrick, and Paul J. Davies. 2009. Thirty financial groups on systemic risk list. Financial Times (November 29).

Kodres, Laura, and Aditya Narain. 2010c. Redesigning the Contures of the Future Financial System. IMF Staff Position Note 10/10 (August 16). Available at www.imf.org (accessed on August 24, 2010).

Lane, Philip R., and Gian Maria Milesi-Ferretti. 2010. The Cross-Country Incidence of the Global Crisis. IMF Working Paper 10/171 (July). Available at www.imf.org (accessed on July 27, 2010).

Levine, Ross. 2009. The Sentinel: Improving the Governance of Financial Policies. In The International Financial Crisis: Have the Rules of Finance Changed? eds. Asli DemirgucKunt, Douglas D. Evanoff, and George G. Kaufman. New Jersey: World Scientific Publishing Co. Pte. Ltd.

McGuire, Patrick, and Götz von Peter. 2009. The US Dollar Shortage in Global Banking and the International Policy Response. BIS Working Paper 219 (October). Available at www.bis.org (accessed on July 30, 2010).

Murphy, Megan, and Patrick Jenkins. 2010. Shares Bounce as Rules Are Softened. Financial Times (July 28).

Obstfeld, Maurice, and Kenneth Rogoff. 2009. Global Imbalances and the Financial Crisis: Products of Common Causes. Paper delivered at Federal Reserve Bank of San Francisco Asia Economic Policy Conference, October 18-20. Available at www.frbsf.org.

Rottier, Stéphane, and Nicolas Véron. 2010. Not All Financial Regulation is Global. Bruegel Policy Brief 2101/07 (August). Available at www.bruegel.org (accessed on August 30, 2010).

Schinasi, Garry J. 2006. Safeguarding Financial Stability: Theory and Practice. Washington: International Monetary Fund.

Schinasi, Garry J. 2007. Causes and Conditions for Cross-Border Threats to Financial Stability. In Cross-Border Banking and National Regulation, eds. George G. Kaufman, et al. London: World Scientific Publishing Company.

Schinasi, Garry J. 2009a. US and EU Reform Efforts in Improving the Management of Systemic Financial Risk. Paper prepared for conference An Ocean Apart? Comparing Transatlantic Responses to the Financial Crisis (September). Rome, Italy.

Schinasi, Garry J. 2009b. More Than One Step Necessary to Financial Stability. Bruegel Policy Brief ISSUE 2009/06 (October).

Schinasi, Garry J. 2009c. The Changing Nature of Systemic Risk. In Toward a New Framework for Financial Stability, eds. David Mayes, Robert Pringle, and Michael Taylor. Central Banking Publications. 
Schinasi, Garry, J., Sean Craig, Burkhard Drees, and Charles Kramer. 2000. Modern Banking and OTC Derivatives: The Transformation of Global Finance and Its Implications for Systemic Risk. IMF Occasional Paper 203. Washington: International Monetary Fund.

Strauss-Kahn, Dominique, and Mario Draghi. 2008. Joint letter addressed to the G-20 finance ministers and central bank governors (November 13). Available at www.financialstabilityboard.org (accessed on July 25, 2010).

Thomson, James B. 2009. On Systemically Important Financial Institutions and Progressive Systemic Mitigation. Federal Reserve Bank of Cleveland Policy Discussion Paper 27 (August). Available at www.clevelandfed.org.

Tietmeyer, Hans. 1999. International Cooperation and Coordination in the Area of Financial Market Supervision and Surveillance (February 11). Tietmeyer Report. Available at www.financialstabilityboard.org (accessed on July 22, 2010).

Truman, Edwin M. 2003. Inflation Targeting in the World Economy. Washington: Peterson Institute for International Economics.

Truman, Edwin M. 2006a. Rearranging IMF Chairs and Shares: The Sine Qua Non of IMF Reform. In Reforming the IMF for the 21st Century, ed. Edwin M. Truman. Washington: Peterson Institute for International Economics.

Truman, Edwin M. 2006b. A Strategy for IMF Reform. Washington: Peterson Institute for International Economics.

Truman, Edwin M. 2008. On What Terms Is the IMF Worth Funding? PIIE Working Paper 08-11 (December). Washington: Peterson Institute for International Economics.

Truman, Edwin M. 2009. The Global Financial Crisis: Lessons Learned and Challenges for Developing Countries (June). Available at www.piie.com.

Truman, Edwin M. 2010a. Dealing with Volatile Capital Flows: The Case for Collective Action. (May). Available at www.piie.com.

Truman, Edwin M. 2010b. The G-20 and International Financial Institution Governance. Peterson Institute for International Economics Workng Paper 10-13 (September).

Truman, Edwin M. 2010c. The IMF and Regulatory Challenges. The International Spectator 45, no. 1: 37-58.

UK Financial Services Authority. 2009. The Turner Review: A regulatory response to the global banking crisis (March).

UK Treasury. 2009. Reforming financial markets (July).

US Treasury. 2009. Financial Regulatory Reform: A New Foundation. Available at www.financialstability.gov. 
Visco, Ignazio. 2009. Global Imbalances in the Financial Crisis and the International Monetary System (December 4). Available at www.bis.org.

Zahler, Roberto. 2010. The FSB: Macroprudential and Counter-Cyclical Regulation. In The Financial Stability Board: An Effective Fourth Pillar of Global Economic Governance? eds. Stephany Griffith-Jones, Eric Helleiner, and Ngaire Woods. Waterloo, Canada: Centre for International Governance Innovation. Available at www.cigionline.org (accessed on July 26, 2010). 